(2) norden 



\section{Økonomien i de nordiske fiskerier}

Fokus på resourcerenten

Max Nielsen, Fødevareøkonomisk Institut, Danmark

Bruno Cozzari, Fødevareøkonomisk Institut, Danmark

Guri Eriksen, Universitetet i Tromsø, Norge

Ola Flaaten, Universitetet i Tromsø, Norge

Eyjolfur Gudmundsson, Universitetet i Akureyri, Island

Jørgen Løkkegaard, Fødevareøkonomisk Institut, Danmark

Kari Petersen, Fcrøernes Landsbank

Staffan Waldo, Livsmedelsekonomiska institutet, Sverige 
Økonomien i de nordiske fiskerier

Fokus på resourcerenten

TemaNord 2006:540

(C) Nordisk Ministerråd, København 2006

ISBN 92-893-1347-1

Tryk: Ekspressen Tryk \& Kopicenter

Omslagsfoto: Birgitta Rydbeck

Oplag: 250

Trykt på miljøvenligt papir som opfylder kravene i den nordiske miljøsvanemærkeordning.

Publikationen kan bestilles på www.norden.org/order. Flere publikationer på

www.norden.org/publikationer

Printed in Denmark

Nordisk Ministerråd

Store Strandstræde 18

1255 København K

Telefon (+45) 33960200

Fax (+45) 33960202

\section{Nordisk Råd}

Store Strandstræde 18

1255 København K

Telefon (+45) 33960400

Fax (+45) 33111870

www.norden.org

\section{Det nordiske samarbejde}

Det nordiske samarbejde er et af de ældste og mest omfattende regionale samarbejder i verden. Det omfatter Danmark, Finland, Island, Norge og Sverige samt Færøerne, Grønland og Åland. Samarbejdet styrker samhørigheden mellem de nordiske lande med respekt for de nationale forskelle og ligheder. Det øger mulighederne for at hævde Nordens interesser i omverdenen og fremme det gode naboskab.

Samarbejdet blev formaliseret i 1952 med Nordisk Råds oprettelse som forum for parlamentarikerne og regeringerne i de nordiske lande. I 1962 underskrev de nordiske lande Helsingforsaftalen, som siden har været den grundlæggende ramme for det nordiske samarbejde. I 1971 blev Nordisk Ministerråd oprettet som det formelle forum til at varetage samarbejdet mellem de nordiske regeringer og de politiske ledelser i de selvstyrende områder, Færøerne, Grønland og Åland. 


\section{Indholdsfortegnelse}

Forord

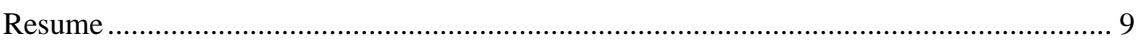

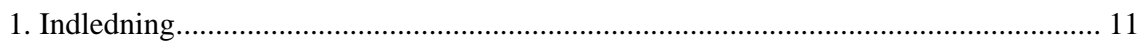

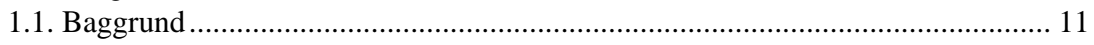

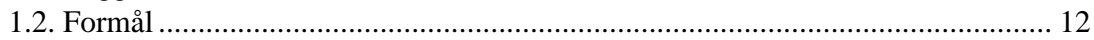

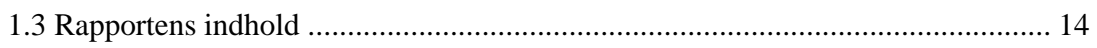

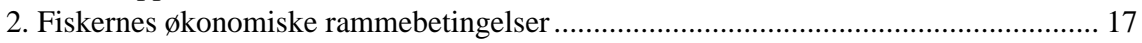

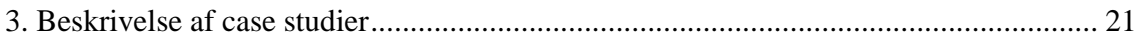

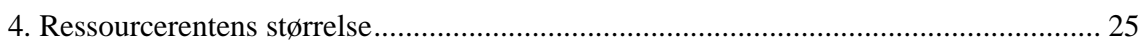

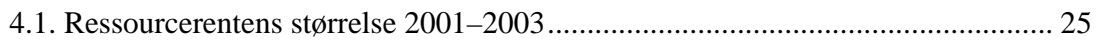

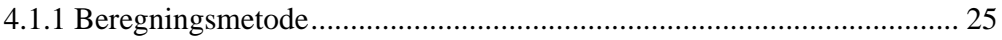

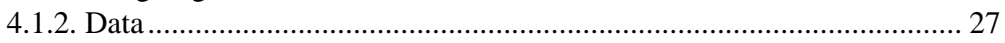

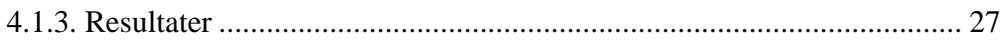

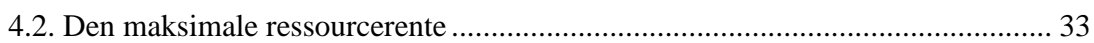

4.2.1 Beregningsmetode............................................................................. 34

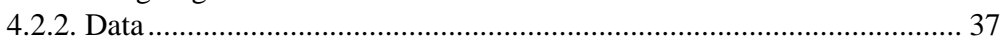

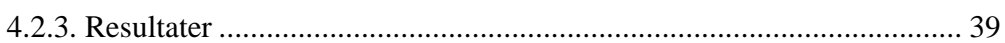

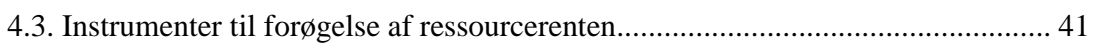

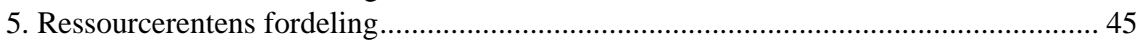

5.1. Ressourcerentens fordeling 2001-2003.......................................................... 46

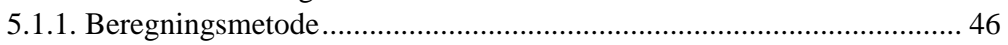

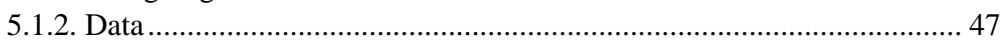

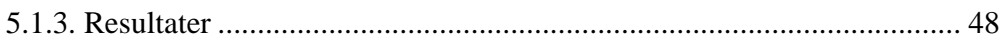

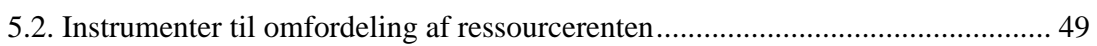

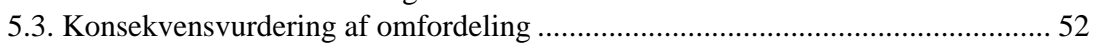

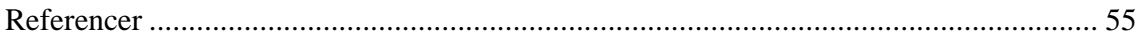

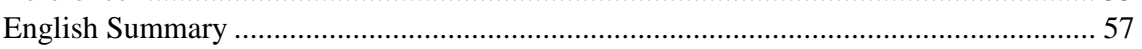

Bilag: Beregning af den maksimale ressourcerente ........................................................ 59 


\section{Forord}

„Økonomien i de nordiske fiskerier - fokus på ressourcerenten“ er resultatet af en undersøgelse foretaget med økonomisk støtte fra Nordisk Ministerråd. Herudover har Livsmedelsekonomiska Institut i Lund bidraget med et svensk case studie. Initiativtager har været Nordisk Embedsmandskomite for Fiskeripolitik ${ }^{1}$.

Undersøgelsens samlede resultater er afrapporteret i nærværende rapport, såvel som i rapporten „Focus on the economy of the Nordic fisheries - case study reports from Iceland, Norway, the Faroe Islands, Sweden and Denmark“. Denne rapport er et fælles ansvar for alle involverede parter, der har forestået arbejdet. Disse er Fødevareøkonomisk Institut i Danmark, Akureyri Universitet i Island, Norges Fiskerihøgskola og Livsmedelsekonomiska Institut i Sverige. Ansvaret for case studie rapporterne påhviler de institutioner, der har stået for udarbejdelsen i deres respektive lande. Den færøske case er udarbejdet af Fødevareøkonomisk Institut med assistance fra Færøernes Landsbank.

Rapporten sætter fokus på samfundsøkonomien i udvalgte nordiske fiskerier med udgangspunkt i ressourcerenten. Ressourcerenten angiver

„det overskud der er tilbage efter aflønning af kapital og arbejdskraft svarende til, hvad der opnås i andre erhverv“.

Ressourcerentens størrelse og fordeling, herunder forøgelse og omfordeling, analyseres. Arbejdet er udført som en økonomisk analyse baseret på et bredt statistisk materiale.

Rapporten er tænkt som et bidrag i den offentlige debat om fiskeriets fremtid i de nordiske lande og målgruppen er politikere, fiskerierhverv og embedsmænd. Rapportens resultater blev fremlagt på konferencen „Økonomisk forvaltning af fiskerierne“, som blev afholdt i Færøerne den 3. 4. maj 2006 af Nordisk Ministerråd og det færøske Fiskeriministerium, men undersøgelsen er udført uafhængigt af denne konference.

Ansvarlig for arbejdet er forskningschef Jørgen Løkkegaard og koordinator adjunkt Max Nielsen, begge Fødevareøkonomisk Institut. Det islandske case er udarbejdet af lektor Eyjolfur Gudmundsson, det norske af professor Ola Flaaten og Guri Eriksen, det svenske af forsker Staffan Waldo og det danske og færøske af forskningsassistent Bruno Cozzari. Økonom Kari Petersen har assisteret i udarbejdelsen af den færøske case og denne rapports kapitel 2 er baseret på Frost, H. (2004), „Naturressour-

\footnotetext{
${ }^{1}$ Nordisk Embedsmandskomité for Fiskeripolitik (NEF) blev pr. 1. januar 2006 omdannet til Embedsmandskomitéen for Fiskeri, Jordbrug, Levnedsmidler og Skovbrug, afdelingen for fiskeri og havbrug (EK-FJLS (fiskeri og havbrug)).
} 
cer som fisk og olie i et frit marked. Det går ikke“, (Samfundsøkonomen). Der har i undersøgelsen været afholdt to projektmøder, hvor der yderligere har været deltagelse af fuldmægtig Majken Pedersen fra Grønlands Hjemmestyre.

Asmundur Gudjonsson

Nordisk Ministerråd, juni 2006. 


\section{Resume}

Traditionelt har biologiske hensyn udgjort kernen i reguleringen af fiskerierne i de nordiske lande. Fiskerireguleringen er baseret på princippet om, at bestandene skal fiskes på et bæredygtigt niveau. Reguleringen har i varierende omfang været rettet mod det økonomiske udbytte for fiskerierhvervet og samfundet. Dette indebærer, at der i de nordiske fiskerierhverv og i de nordiske samfund er et væsentligt potentiale for at forøge det økonomiske udbytte af fiskebestandene ved en reduktion i den investerede kapital i fiskefartøjer.

Formålet med denne rapport er at fokusere på fiskerireguleringer, der sikrer et større vedvarende økonomisk udbytte af fiskeriet, herunder på hvem udbyttet tilfalder og hvordan det fordeles mellem erhvervet og det offentlige.

Rapporten tager udgangspunkt i følgende cases:

1. Trawlerfiskeriet i Island, reguleret ved individuelt omsættelige kvoter.

2. Kystfiskeriet i Norge, reguleret ved individuelt ikke omsættelige kvoter.

3. Partrawlerfiskeriet i Færøerne, reguleret ved havdage.

4. Stimefiskeri i Sverige reguleret ved rationer.

5. Muslingefiskeri i Danmark reguleret ved licenser.

Det samfundsmæssige udbytte måles ved ressourcerenten, som angiver „det overskud der er tilbage efter aflønning af kapital og arbejdskraft svarende til, hvad der opnås i andre erhverv". Ressourcerenten i 20012003 udgør fra $60 \%$ af landingsværdien i det danske muslingefiskeri, til -22 \% i det norske kystfiskeri. I Island og Færøerne udgør ressourcerenten hhv. $30 \%$ og $28 \%$, i Sverige $3 \%$.

Den maksimale ressourcerente beregnes i en bio-økonomisk model under en række antagelser om biologi, økonomi, flådestruktur og fiskerimønster. Under disse antagelser identificeres en maksimal ressourcerente i det danske muslingefiskeri på $69 \%$ af landingsværdien, lidt lavere i Island (60 \%), Sverige (53 \%) og Færøerne (47 \%) og lavest i Norge (18 \%).

En målsætning om at opnå den maksimale ressourcerente vil dog ikke nødvendigvis være i overensstemmelse med de øvrige fiskeripolitiske målsætninger, herunder om regionalpolitik, beskæftigelse, bosætning og ønsker om en bestemt flådestruktur. Målet om at opnå den størst mulige ressourcerente skal derfor prioriteres sammen med de øvrige fiskeripolitiske målsætninger. Den maksimale ressourcerente kan opnås gennem bed- 
re fiskeriforvaltning med fokus på biologi, økonomi og automatisk strukturtilpasning.

Fordelingen af ressourcerenten mellem kapital, arbejdskraft og offentlige myndigheder (efter fradrag af offentlige nettoudgifter til fiskeriet, herunder fiskeriforvaltningsomkostninger) angiver, at offentlige myndigheder alene opnår en positiv andel af ressourcerenten i Island og Danmark. I Norge, Færøerne og Sverige er de offentlige myndigheders andel af ressourcerenten negativ. Dvs. samtidig med at samfundet, jf. fiskerilovgivningerne i flere af de nordiske lande ejer fiskebestandene, er det offentliges nettoudbytte af tilstedeværelsen af fiskerisektoren i de tre lande negativ.

Ressourcerenten er efter fradrag af offentlige nettoudgifter til fiskeriet negativ i Norge og Sverige, men fordelingen angiver, at aflønningen af arbejdskraft i begge lande er nogenlunde på niveau med andre erhverv. Kapitalaflønningen er lavere i Norge, men større i Sverige. Den positive ressourcerente i Island og Færøerne er fordelt med mest til arbejdskraft og mindre til kapital. I Danmark og Norge er fordelingen mellem arbejdskraft og kapital påvirket af, at fartøjerne er små og ejerne i en række tilfælde både er arbejdskraft og ejere af kapital.

Ressourcerenten kan omfordeles fra kapital og arbejdskraft til samfundet. Dette kan ske på en række måder, herunder ved at introducere afgift på landinger, ved at afskaffe tilskud til fiskeriet og ved at opkræve fiskeriforvaltningsomkostninger. Mulighederne begrænses dog i de tilfælde, hvor de nuværende fiskere har købt og betalt deres fiskerirettigheder til tidligere fiskere.

Det understreges, at resultaterne i rapporten bygger på en række beregningsforudsætninger, både hvad angår størrelse og fordeling af ressourcerenten samt af den maksimale ressourcerente. Resultaterne er derfor behæftet med usikkerhed og må nødvendigvis fortolkes med forsigtighed. 


\section{Indledning}

\subsection{Baggrund}

Traditionelt har biologiske hensyn udgjort kernen i reguleringen af fiskerierne i de nordiske lande. Fiskerireguleringen er baseret på princippet om, at bestandene skal fiskes på et bæredygtigt niveau (forsigtighedsprincippet). Reguleringen har i varierende omfang været rettet mod det økonomiske udbytte for fiskerierhvervet og samfundet. Det er til en vis grad lykkedes at holde fiskeriet på et biologisk bæredygtigt niveau, selvom der er adskillige undtagelser, men det er ikke lykkedes helt at fokusere på økonomien i fiskerierne. Dette på trods af at et grundvilkår i fiskerierhvervet er, at ,fiskerne fisker for at tjene penge“.

Dette indebærer, at der i de nordiske fiskerierhverv og i de nordiske samfund er et væsentligt potentiale for at forøge det økonomiske udbytte af fiskebestandene. I et fuldstændigt ureguleret fiskeri er det eneste udbytte af fiskeriet, at mandskabet får løn og den investerede kapital forrentes alene for de få dygtigste fiskere. Der er imidlertid ingen aflønning af fiskeressourcerne; forbedrede bestandforhold vil bare betyde, at der kommer flere fiskere til erhvervet, og forværrede bestandforhold, at fiskere forlader erhvervet. Så snart der indføres forvaltning i fiskeriet, om det så er ved kvoter, licenser eller andet, kan det generere et positivt økonomisk afkast af fiskebestandene. Dette økonomiske afkast vil være større des lavere omkostningerne er ved at fiske en bæredygtig mængde fisk.

Potentialet for at forøge det økonomiske udbytte af de nordiske fiskerier er ikke kun relateret til, at omkostningerne ved fiskeri for det enkelt fartøj kan reduceres, men til at der kan være „for mange fiskere om at fiske for få fisk“. Midlet til at opnå et økonomisk udbytte af de nordiske fiskerier er at tildele eksklusive rettigheder i form af fiskerirettigheder til at udnytte fiskebestandene. Ved at tildele et begrænset antal fiskere, inklusiv fiskekooperativer og regionale institutioner, eksklusive rettigheder til de fiskeressourcer, som staterne i alle de nordiske lande, jf. fiskerilovgivningerne, har kontrol over, skabes basis for et økonomisk afkast af ressourcerne. Det økonomiske udbytte, der skabes herved, kan tilfalde fiskerne og/eller samfundet, afhængigt af om samfundet forærer fiskerirettighederne væk, sælger dem eller opkræver skat på de indkomster, der genereres. 


\subsection{Formål}

Formålet med projektet er at analysere mulighederne for at fremme anvendelsen af fiskerireguleringer, der fokuserer på at opnå et større vedvarende økonomisk udbytte af fiskeriet, herunder at fokusere på størrelsen af udbyttet, hvem det tilfalder og hvordan det fordeles mellem erhvervet og samfundet.

Der fokuseres på to områder. Størrelsen af det økonomiske udbytte, hvad det er i dag, hvad det kan blive, hvis der føres en fiskeripolitik, der alene sigter mod at skabe det maksimale økonomiske udbytte på lang sigt, samt hvordan man opnår et større økonomisk udbytte. Det andet er fordelingen af det økonomiske udbytte mellem kapital, arbejdskraft og samfund, hvordan den er i dag, hvilke instrumenter der kan anvendes i en omfordeling og hvem der kommer til at bære byrderne heraf.

Det økonomiske udbytte af fiskeriet måles i nærværende rapport som ressourcerenten, som angiver „det overskud der er tilbage efter aflønning af kapital og arbejdskraft svarende til, hvad der opnås i andre erhverv“. Ressourcerenten er et mål for den økonomiske effektivitet, men er ikke det samme som overskud. Hvor overskud siger noget om driftsøkonomi, siger ressourcerenten noget om samfundsøkonomien. Der sættes således fokus på nordisk fiskeri i et samfundsøkonomisk perspektiv, som angivet i figur 1.

Figur 1. Forøgelse og omfordeling af ressourcerenten i fiskeriet.

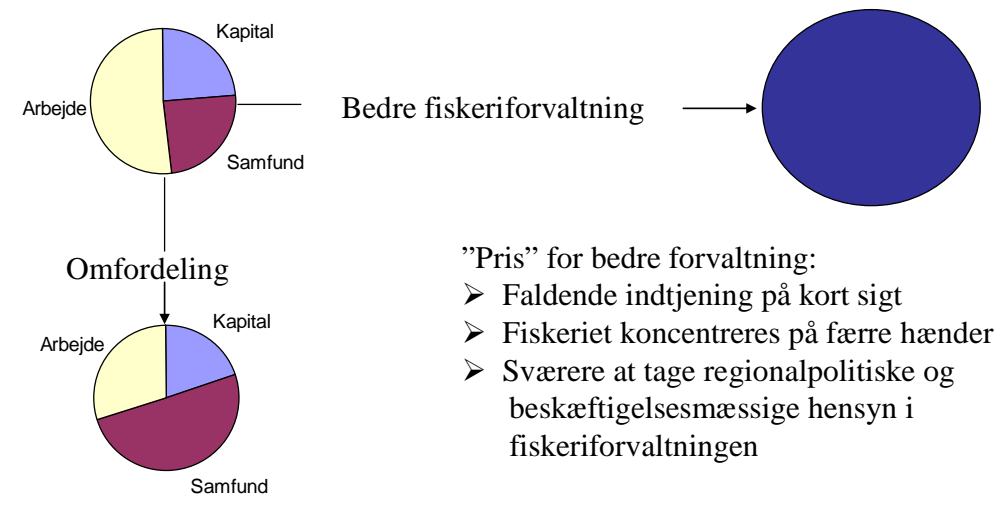

De to emner, der fokuseres på, er at forøge den nuværende ressourcerente gennem bedre fiskeriforvaltning og at omfordele ressourcerenten fra kapital og arbejdskraft til samfundet. For at simplificere analysen gennemgåes de to emner hver for sig, først ressourcerentens størrelse og derefter fordelingen. I praksis vil der imidlertid være et samspil mellem dem. Teoretisk vil det være at foretrække at introducere omfordeling, $\mathrm{fx}$ i form af beskatning, samtidig med bedre fiskeriforvaltning. Årsagen er, at når 
fiskeriforvaltningen forbedres i form af fx foræring af omsættelige fiskerirettigheder til aktive fiskere, vil disse fiskere blive pålagt skattebyrden. I praksis vil det dog normalt være sådan, at det er svært at komme igennem med at introducere beskatning, før det fremstår klart, at der rent faktisk er en ressourcerente, dvs. noget tid efter at fiskeriforvaltningen er blevet forbedret.

Ressourcerenten identificeres i nærværende rapport uden at tage hensyn til, at indenlandsk arbejdskraften kan erstattes af billigere udenlandsk arbejdskraft.

Fokus i rapporten er på ressourcerenten, på trods af at denne ikke i noget nordisk land er formuleret som det eneste formål i fiskeripolitikken. Målsætningerne i fiskeripolitikken i de nordiske lande spænder bredt og inkluderer ud over ressourcerenten, driftsøkonomisk overskud, regionalpolitiske forhold som bosætning og beskæftigelse, samt flådepolitik i relation til fx kystfiskeri. Det understreges, at rapporten ikke beskæftiger sig med prioriteringen af disse målsætninger, men det nævnes, at fiskebestandene i flere nordiske landes fiskerilovgivninger er angivet som samfundets eje.

I rapporten beregnes den maksimale ressourcerente uden hensyntagen til de øvrige fiskeripolitiske målsætninger, hvilket i mange tilfælde vil være i konflikt med målsætninger om beskæftigelse, bosætning og tilstedeværelsen af kystfiskeri med mindre fartøjer. Den maksimale ressourcerente angiver således alene, hvad der kan opnås. Rapporten tager ikke stilling til, om der bør føres en politik, der sigter mod at forøge ressourcerenten, eller om politiske målsætninger om beskæftigelse, bosætning og tilstedeværelsen af kystfiskeri med mindre fartøjer skal prioriteres højere. I rapporten konkluderes alene, at hvis det ønskes, er der et væsentligt potentiale i at forøge ressourcerenten og derved det samfundsøkonomiske udbyttet af fiskeriet i alle de fem analyserede nordiske cases.

I rapporten beregnes endvidere fordelingen af den nuværende ressourcerente, ligesom konsekvenser af omfordeling fra kapital og arbejdskraft til samfundet analyseres. Dette indebærer ikke, at det foreslås, at ressourcerenten skal omfordeles, men alene at det vises at ressourcerenten kan omfordeles, samt hvilke konsekvenser det konkret kan få. Usynlig ressourcerente som tilfalder første generations rettighedshavere, som solgte sine rettigheder og trak sig ud af fiskerierhvervet, inddrages også i overvejelserne. Endelig relateres fordelingen af synlig og usynlig ressourcerente mellem fiskerierhvervet og det offentlige kort til forhold vedr. råstofudvinding og landbrug.

Der tages udgangspunkt i de meget forskelligartede fiskerireguleringer, der i dag findes i de nordiske lande. Dette sker ved at inkludere fem case studier ud fra, at de skal repræsentere „rene“ reguleringsinstrumenter med henblik på at belyse de enkelte instrumenters økonomiske effekter. De valgte cases, som samtidig er fra fem forskellige nordiske lande, er: 
1. Individuelt omsættelig kvotereguleret trawlerfiskeri i Island.

2. Individuelt ikke-omsættelig kvotereguleret kystfiskeri i Norge.

3. Havdagereguleret partrawlerfiskeri i Færøerne.

4. Rationsreguleret stimefiske fiskeri i Sverige

5. Licensreguleret muslingefiskeri i Danmark

Arbejdet baseres på eksisterende viden om fiskeøkonomiske reguleringsinstrumenter, på bio-økonomiske modelberegninger, samt økonomiske fordelings analyser. Der anvendes offentliggjorte informationer, statistikker og undersøgelser om de nordiske fiskerier. Hvor der eksisterer relevante erfaringer og hvor lande udenfor Norden er nået længere end de nordiske lande, vil disse erfaringer blive inddraget.

Det er ideen i rapporten at bruge eksisterende litteratur om fiskeøkonomiske reguleringsinstrumenter og anvende denne i forhold til en konkret analyse af ressourcerenten i sammenhæng med reguleringsinstrumenterne i de udvalgte fiskerier. Intentionen er at formidle denne viden videre til en bred kreds af politikere, erhvervsfolk og embedsmænd.

Det understreges at resultaterne, både hvad angår beregningen af størrelse og fordeling af ressourcerenten samt af den maksimale ressourcerente, bygger på en række beregningsforudsætninger. Alle resultater er således behæftet med en betydelig usikkerhed. I beregningen af den faktiske ressourcerente i 2001-2003 er usikkerheden i særdeleshed relateret til fastsættelsen af aflønning af arbejdskraft og kapital i alternativ anvendelse. I beregningen af den maksimale ressourcerente er der yderligere usikkerhed på både biologiske og økonomiske data såvel som på selve beregningsmodellen i en situation, som forudsætter væsentlige strukturelle ændringer i flådesegmenterne. Beregningen af fordelingen af ressourcerenten baseres på de samme tal og usikkerheden er derfor også til stede i disse beregninger. Dette indebærer at resultaterne skal fortolkes med forsigtighed.

\subsection{Rapportens indhold}

Rapporten indeholder ud over indledningen fire kapitler. I kapitel 2 beskrives fiskernes økonomiske rammebetingelser ud fra en teoretisk indfaldsvinkel. Udgangspunktet er eksisterende viden indenfor generel ressource- og fiskeriøkonomi. Fiskeri og fiskeriregulering beskrives i et økonomisk perspektiv, ressourcerente introduceres, forudsætningerne for at der eksisterer ressourcerente gennemgås og eksisterende viden om økonomiske reguleringsinstrumenter beskrives.

I kapitel 3 gennemgås strukturen i de fem udvalgte fiskerier, og de eksisterende fiskerirettigheder og fiskerireguleringer beskrives. Nøgletal for de fem udvalgte fiskerier gennemgås og det beskrives, hvem der kan tildeles adgang til erhvervsmæssigt fiskeri. Dvs. hvem der kan få rettig- 
heder til fiskeri og efter hvilke principper. Endvidere gennemgås forhold med relation til fiskerireguleringer, herunder indviduelle kvoter, fiskedage, omsættelighed, salg af fiskerirettigheder og ejendomsret til fiskerirettigheder.

I kapitel 4 beregnes størrelsen af den nuværende og maksimale ressourcerente i de udvalgte fiskerier og det vurderes, hvordan ressourcerenten kan forøges.

I kapitel 5 beregnes fordelingen af den nuværende ressourcerente mellem fiskerierhverv og samfund, samtidig gennemgås de generelle muligheder for at inddrive ressourcerenten og byrdefordeling i forbindelse hermed analyseres.

I rapporten indgår et bilag med en teknisk gennemgang af den bioøkonomiske model, der anvendes til at beregne den maksimale ressourcerente.

Beregningerne i nærværende rapport er baseret på data fra rapporten „Focus on the economy of the Nordic fisheries - case study reports from Iceland, Norway, the Faroe Islands, Sweden and Denmark“. For en detaljeret gennemgang af de data som er anvendt i nærværende rapport henvises derfor til denne rapport. Såfremt der er væsentlige forskelle i tal mellem nærværende rapport og case studierne, vil dette være nævnt i fodnoter i denne rapport. 


\section{Fiskernes økonomiske rammebetingelser}

Fælles ejendomsret, eksterne effekter og manglende prisfastsættelse er opskriften på, at et frit marked ikke kan fungere samfundsøkonomisk optimalt. Disse forhold karakteriserer udnyttelsen af fiskebestandene, såfremt der ikke anvendes en hensigtsmæssig fiskeriforvaltning.

Fiskeriet er karakteriseret af uklare ejendomsretsforhold herunder en uklar fordeling af gevinster ved udnyttelse af fiskebestandene. Årsagen er, at samfundet i princippet ejer fiskebestandene, som udnyttes af mange brugere. Fiskeriet er endvidere karakteriseret ved tilstedeværelsen af såkaldte eksterne effekter dvs. forhold, der ikke direkte indgår i fiskernes økonomiske overvejelser. Eksterne effekter forekommer i form af, at den enkelte fiskers aktivitet påvirker andre fiskeres fangstmuligheder negativt. Dette fører til „for få fisk til for mange fiskere“. Konsekvensen er forkert prisfastsættelse på markedet, da priserne på fisk ikke afspejler de manglende fremtidige fangstmuligheder, som overudnyttelse indebærer.

I den fiskeriøkonomiske teori vises, at når der er fri adgang til fiskeriet, tilpasser man sig, så fiskeriindsatsen bliver for stor, fiskebestanden bliver for lille, og der tilvejebringes ingen ressourcerente (Warming 1911, 1931, Gordon 1954 og Clark 1990). Fiskerne kan imidlertid sagtens drive et fiskeri med en rentabilitet på niveau med andre erhverv. For samfundet som helhed bindes der imidlertid produktionsfaktorer i fiskeriet i et omfang, så faktoraflønningen i fiskeriet er på niveau med det øvrige samfund. Der er for mange fiskere til at fiske for få fisk og de fiskere, der er for mange, kunne bidrage mere til samfundsøkonomien ved at arbejde i andre erhverv. Også kapitalen kunne investeres i andre erhverv med større samfundsøkonomisk udbytte. Konsekvensen er, at fiskeriforvaltning er nødvendig, hvis fiskeriet skal generere en ressourcerente.

Udviklingen i fiskerisektoren verden over har ændret det frie fiskeri, via oprettelsen af eksklusive økonomiske zoner (200 sømil grænsen) i slutningen af 1970'erne og starten af 1980'erne. Introduktionen af eksklusive økonomiske zoner betød, at kyststater fik kompentence til at forvalte fiskeriet indenfor deres nationale zone i modsætning til tidligere, hvor fartøjer af alle nationaliteter havde frit fiskeri udenfor kystzonegrænsen i princippet i hele verden. I de efterfølgende årtier er der i forskelligt omfang introduceret fiskeriforvaltning med udgangspunkt $\mathrm{i}$, at biologisk forvaltning kan sikre fremtidige fangstmuligheder, hvor økonomisk forvaltning kan sikre, at omkostningerne ved at fiske bliver så små som muligt. Dette har ført til, at der i mange lande gradvist er indført strammere fiskeriforvaltning gennem adgangsbegrænsninger, fartøjs- og 
kapacitets-begrænsninger, kvotebegrænsninger, indsatsbegrænsninger, begrænsninger i hvilke områder, der tillades fiskeri samt begrænsninger i muligheden for at anvende bestemte redskaber.

Effekten af de forskellige typer fiskeriforvaltning er meget forskellig. I nogle få lande er man tæt på en fiskeriforvaltning, der sikrer det maksimalt mulige samfundsmæssige udbytte af fiskeriet. Andre steder er der reelt stadig frit fiskeri. I de fleste lande er man imidlertid et sted imellem. Der er skabt en positiv ressourcerente, som dog stadig ligger langt under, hvad der kunne opnås med en optimal fiskeriforvaltning. Ressourcerenten kan således forøges, både gennem en forøgelse af fangsterne og ved en reduktion i de samfundsmæssige omkostninger. Fiskeriforvaltningen synes endvidere at blive stadig mere hensigtsmæssig ud fra en samfunds$ø$ konomisk betragtning i de fleste lande.

I mange lande er der således en situation, hvor der gradvist genereres en større ressourcerente. I en sådan situation påkalder fordelingen af ressourcerenten sig særlig interesse. Flere lande angiver i fiskerilovgivningerne, at fiskebestandene ejes af samfundet repræsenteret ved den offentlige sektor. Samtidig har fiskeriet været udøvet i århundreder og fiskerne ser det som en velerhvervet rettighed at fiske og derigennem tjene penge. Yderligere indebærer det generelle skattesystem, at både arbejdskraft og kapital beskattes af deres fiskeriaktiviteter og herigennem betaler en del af en evt. ressourcerente til den offentlige sektor. Omvendt har den offentlige sektor udgifter til fiskeriet i form af tilskud, gennemførsel af kontrol, biologiske undersøgelser og rådgivning.

En af hovedårsagerne til, at der gradvist genereres større overskud og ressourcerente i mange lande, er, at der indføres adgangsbegrænsninger til fiskeri, dvs. at en begrænset gruppe fiskere tildeles eksklusive rettigheder til fiskeri. Herved undgås, at der kommer for mange nye fiskere ind i fiskeriet, hvilket samfundsøkonomisk er fordelagtigt. Men sideeffekten er, at fordi tidligere rettighedshavere enten har fået tildelt fiskerirettigheder gratis (første generations rettighedshavere) eller har købt rettigheder på et tidspunkt, hvor ressourcerenten var mindre og prisen på rettigheder derfor lav, har de fået foræret ressourcerenten. Når nye generationer fiskere skal ind i fiskeriet, skal de købe deres rettigheder, enten særskilt eller tilknyttet fartøjerne, og betale de gamle fiskere. Derved er det kun de „gamle“ generationer af fiskere, der vinder ved tildeling af eksklusive rettigheder, nyere generationer af fiskere vinder kun, hvis ressourcerenten bliver ved med at stige. Såfremt perfekt forvaltning introduceres med et slag i et ,jomfrueligt fiskeri“dvs. et helt nyt fiskeri, tilfalder hele ressourcerenten første generations rettighedshavere. Har fiskeriet eksisteret i årevis, som tilfældet er med de fem udvalgte fiskerier i denne rapport, og forbedres fiskeriforvaltningen gradvist over en årrække, får generationer, der er aktive over hele forbedringsperioden andel i ressourcerenten.

Billedet af hvem, der får andel af en evt. ressourcerente, er således ikke entydigt. Derfor er det heller ikke entydigt klart, hvem der kan beskat- 
tes. Specielt ikke da ressourcerenten er vanskelig at beregne præcist og samtidig ændre sig over tid. Disse vanskeligheder gør det imidlertid blot mere påkrævet med en fornuftig fiskeriforvaltning suppleret med en fornuftig fordelingspolitik.

Med udgangspunkt i det ovenfor beskrevne grundlag for fiskernes økonomiske rammebetingelser, identificeres ressourcerentens størrelse og fordeling, samt potentialet for forøgelse og omfordeling i fem udvalgte nordiske fiskerier i de følgende kapitler. 


\section{Beskrivelse af case studier}

I nærværende rapport sættes fokus på ressourcerentens størrelse og fordeling i forskellige fiskerier. Der er udvalgt fem case studier med henblik på at fremhæve mangfoldigheden i det nordiske fiskeri og repræsentere forskellige forvaltningsregimer. De fem case studier er:

1. Trawlerfiskeriet i Island, reguleret ved individuelt omsættelige kvoter.

2. Kystfiskeriet i Norge, reguleret ved individuelt ikke omsættelige kvoter.

3. Partrawlerfiskeriet i Færøerne, reguleret ved havdage.

4. Stimefiskeri i Sverige reguleret ved rationer.

5. Muslingefiskeri i Danmark reguleret ved licenser.

De fem case studier er yderligere valgt med udgangspunkt i tilgængeligheden af data og med henblik på at repræsentere fiskerier med forskellig rentabilitet. Endelig stammer de fem fiskerier fra lande med forskellig afhængighed af fiskeriet.

Nøgletal for de fem fiskerier (flådesegmenter) er angivet i tabel 1 som årlige gennemsnit for 2001-2003. For Norge er tallene dog et gennemsnit af 2003-2004, da flådesegmenteringen ændres i 2003.

Tabel 1. Nøgletal for de udvalgte fiskerier.

\begin{tabular}{lrrrrr}
\hline & Island & Norge & Færøerne & Sverige & Danmark \\
\hline Beskæftigelse $^{1}$ & 2.100 & 1.870 & 322 & 344 & 75 \\
Landingsværdi (mio. DKK) $_{\text {Antal fartøjer }}^{2.543}$ & 793 & 302 & 387 & 133 \\
Tonnage (gns. BT) & 76 & 1.145 & 29 & 57 & 63 \\
Motorkraft (gns. HK) & 1.044 & 13 & 352 & 381 & 20 \\
Forsikringsværdi (gns. Mio. DKK) & 1.869 & 159 & 1.262 & 1.144 & 129 \\
Antal havdage (gns.) & 35 & 2 & 12 & 19 & 2 \\
Andel af total landingsværdi (\%) & 267 & 171 & 244 & 203 & 203 \\
& 42 & 9 & 21 & 46 & 4
\end{tabular}

Noter: 1. Angiver fuldtidsbeskæftigelsen, som for Island, Færøerne og Sverige er estimeret på grundlag af at en fuldtidsansat fisker deltager $\mathrm{i}$ to fangstrejser og holder fri en. For Norge og Danmark er fuldtidsbeskæftigelsen estimeret på grundlag af antallet af havdage, da fangstrejer normalt ikke varer længere end en dag.

2. Den totale landingsværdi er angivet for fiskeri uden fjernfiskeri. Dette er rimeligt i alle lande, der ikke har betydeligt fjernfiskeri, dvs. alle lande ekskl. Færøerne. Medregnes det færøske fjernfiskeri i perioden udgør partrawlersegmentets andel af den samlede landingsværdi $13 \%$.

Kilder: Nødvendige data for at udarbejde denne tabel er angivet i rapporten „Focus on the economy of the Nordic fisheries - case study reports from Iceland, Norway, the Faroe Islands, Sweden and Denmark".

Beskæftigelsen målt som fuldtidsansatte er største i det islandske trawlerfiskeri og det norske kystfiskeri, på samme niveau i det svenske stimefiskeri og det færøske partrawlerfiskeri og mindst i det danske muslingefiskeri. Omsætningen er størst i Island med 2.543 mio. DKK, hvilket er ca. tre gange så stort som i det norske kystfiskeri. Omsætningen i de svenske 
og færøske flådesegmenter udgør en sjettedel af omsætningen i det islandske trawlerfisker. Det danske muslingefiskeri er det mindste flådesegment.

Antallet af fartøjer er med 1.145 langt det største i Norge, på niveau i Island, Danmark og Sverige og lavest i Færøerne. Fartøjsstørrelsen er imidlertid meget forskellig. Det islandske trawlerfiskeri udøves af meget store fartøjer, der normalt er på lange fangstrejser og har skiftende besætninger. De islandske fartøjer er således størst, både når der måles i tonnage, motorkraft, forsikringsværdi og størrelsen af besætningen. De svenske og færøske fartøjer er med 6-12 fuldtidsansatte, gennemsnitligt ca. 350 BT og $1.200 \mathrm{HK}$ og med forsikringsværdier på 19 og 12 mio. DKK af mellemstørrelse. De danske og norske fartøjer er meget små med 1-2 mandsbesætninger og i mange tilfælde med fartøjsejeren som den ene.

Størrelsen af fartøjerne afspejles i kapacitetsudnyttelsen, hvor de islandske og færøske fartøjer er på havet i flest dage om året. De forholdsvis store svenske fartøjer har et lavere antal havdage, hvilket hænger sammen med forvaltningsmæssige begrænsninger. Antallet af havdage er i det danske muslingefiskeri på niveau med Sverige på trods af, at fartøjerne er meget små. I det norske kystfiskeri er fartøjerne på havet gennemsnitligt 171 dage om året. Dette lavere tal skal ses i sammenhæng med, at fiskeriet er sæsonbetonet og de fiskearter, der fiskes på, kun er til stede i farvande, som er tilgængelige for små fartøjer i en del af året.

Det svenske og islandske flådesegmenter udgør den største andel af de nationale fiskerier, hhv. 46 \% og $42 \%$. I Danmark udgør muslingefiskeriet kun $4 \%$ af den samlede landingsværdi og i Norge udgør kystfiskeriet $9 \%$. De svenske og islandske flådesegmenter udgør således næsten halvdelen af de nationale fiskerier, hvor de danske og norske er af mere begrænset betydning. Det norske kystfiskeri bidrager dog med en høj beskæftigelse i tyndt befolkede yderområder. Det færøske partrawlersegment udgør en femtedel af det færøske fiskeri i færøsk farvand. Medregnes også andre færøske flådesegmenters forholdsvist betydningsfulde fjernfiskeri i bl.a. Barentshavet, udgør partrawlersegmentet kun $13 \%$ af det samlede færøske fiskeri.

De fem udvalgte flådesegmenters vigtigste fiskearter er angivet i tabel 2. Tabellen inkluderer alene arter, der bidrager med mindst $10 \%$ af landingsværdien. 
Tabel 2. Landinger af de udvalgte flådesegmenter, gennemsnit af 2001-2003.

\begin{tabular}{|c|c|c|c|c|c|}
\hline & Island & Norge & Færøerne & Sverige & Danmark \\
\hline \multicolumn{6}{|c|}{ Landingsværdi (mio. DKK): } \\
\hline - torsk & 894 & 424 & 70 & . & . \\
\hline - kuller & . & 53 & 33 & . & . \\
\hline - sej & . & 52 & 158 & . & . \\
\hline - rødfisk & 649 & . & . & . & . \\
\hline - sild & . & . & . & 179 & . \\
\hline - tobis & . & . & . & 41 & . \\
\hline - brisling & . & . & . & 72 & . \\
\hline - blåmusling & . & 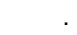 & . & . & 130 \\
\hline - andet & 1.000 & 264 & 41 & 90 & 3 \\
\hline - total & 2.543 & 793 & 302 & 387 & 133 \\
\hline \multicolumn{6}{|c|}{ Landingsmængde (1.000 tons): } \\
\hline - torsk & 81 & 43 & 4 & . & . \\
\hline - kuller & . & 9 & 3 & . & . \\
\hline - sej & . & 15 & 35 & . & . \\
\hline - rødfisk & 96 & . & . & . & . \\
\hline - sild & . & . & . & 94 & . \\
\hline - tobis & . & . & . & 43 & . \\
\hline - brisling & . & . & . & 74 & . \\
\hline - blåmusling & . & . & . & . & 109 \\
\hline - andet & 197 & 30 & 10 & 41 & 2 \\
\hline - total & 375 & 97 & 52 & 250 & 111 \\
\hline
\end{tabular}

Note: 1 . Inkluder alle arter der omfatter mere end $10 \%$ af landingsværdien.

Kilder: Nødvendige data for at udarbejde denne tabel er angivet i rapporten „Focus on the economy of the Nordic fisheries - case study reports from Iceland, Norway, the Faroe Islands, Sweden and Denmark".

Det fremgår, at de islandske, færøske og norske flådesegmenters fiskeri er målrettet bundfisk, det danske blåmusling og det svenske stimefisk. Den vigtigste bundfisk er torsk i Island og Norge. I Island er rødfisk yderligere meget betydningsfuld. Det færøske partrawlerfiskeri er primært målrettet sej, men torsk og kuller er også vigtige. Den vigtigste art i det svenske stimefiskeri er sild, men brisling og tobis er også betydningsfulde. De islandske, færøske, norske og danske flådesegmenters fiskeri foregår i nationale farvande, det færøske primært på Færø Plateauet, det norske i kystnære områder langs hele kysten bl.a. på fællesbestande med Rusland og det danske primært i Limfjorden. Det svenske fiskeri er mere spredt, sild fanges både i Skagerrak, Kattegat, Nordsøen og i Østersøen, brisling i Østersøen og tobis i Nordsøen.

De fem udvalgte flådesegmenter forvaltes ved anvendelse af en lang række instrumenter. Disse inkluderer tekniske bevaringsforanstaltninger som maskestørrelse og maskevidder, adgangsbegrænsninger for fartøjer og kapacitet, såvel som indsatsforvaltning med havdage og kvoteregulering. Fiskerirettighederne er i forskelligt omfang omsættelige, enten særskilt eller i forbindelse med salg af fartøjer. Der eksisterer adgangsbegrænsninger og tekniske bevaringsforanstaltninger i alle de fem fiskerier, såvel som fiskeriforvaltningen i alle de fem lande baserer sig på rådgivning om bæredygtigheden vurderet ved fiskeridødelighed og gydebiomasse. Nedenstående gennemgås de centrale forvaltningsinstrumenter anvendt i hvert af de fem udvalgte fiskerier.

I det islandske trawlerfiskeri er individuelt omsættelige kvoter det helt bærende element. Individuelt omsættelige kvoter blev introduceret tilbage 
i 1980'erne og er efterfølgende gradvist udvidet til at omfatte hele det islandske fiskeri. Siden 1990'erne er der endvidere taget en række initiativer til at begrænse det samlede fiskeri til totalkvoten, samt til at imødegå stigende kritik af den koncentration, som det individuelle kvotesystem har forårsaget. Disse initiativer inkluderer fjernelse af subsidier, inddragelse af små og mindre fartøjer i det individuelle kvotesystem og introduktion af en afgift på ejerskab af fiskerirettigheder.

I torskefiskerierne i Norge, som er det vigtigste for kystflåden, er forvaltningen meget forskelligartet, men det centrale er individuelle fartøjskvoter. Disse er samlekvoter af torsk, kuller og sej, som omregnes til torskeækvivalenter, hvor fartøjsejeren frit kan vælge mellem de tre arter. Fartøjskvoterne er ikke omsættelige. Endvidere eksisterer en ordning, hvor der opkræves en landingsafgift på 0,2 \% til en strukturfond, som tildeles fartøjer under 15 meter, der ophører med fiskeri. Endelig baserer fiskeriforvaltningen i Barentshavet sig på et bilateralt samarbejde med Rusland.

I det færøske partrawlerfiskeri er indsatsregulering i form af begrænsninger i antallet af havdage et af de to centrale forvaltningsinstrumenter. Det andet er et restriktivt system, hvor bestemte områder lukkes i bestemte perioder for bestemte flådesegmenter. Subsidier har tidligere været anvendt i det færøske fiskeri men er næsten afskaffet over de senere år.

Det svenske stimefiskeri forvaltes med rationer (mængder), der løber i to uger af gangen, hvorpå der kan fiskes indtil rationen er opbrugt. Alle svenske erhversfiskerier har ret til at fiske efter de aktuelle arter, hvilket indebærer, at kapaciteten som udnytter arterne kan variere. Endvidere er et centralt forvaltningsinstrument offentlig ophørsstøtte, hvor det ikke tillades, at fartøjer erstattes af andre og nye. Endvidere gives støtte til nybygning, hvortil et krav er, at der skal udtages 30 \% større kapacitet, end der indsættes.

I det danske muslingefiskeri er det bærende element i forvaltningen en restriktiv kapacitetsbegrænsning. Denne kombineres med anvendelsen af daglige og ugentlige kvoter og periodelukninger. Kvoter og periodelukninger fastsættes med indflydelse fra fiskerne (co-management). Periodelukningerne baseres bl.a. på, at kvaliteten af muslingerne falder i perioder med varmt vand. 


\section{Ressourcerentens størrelse}

Ressourcerenten defineres som „det nettooverskud der er tilbage til aflønning af kapital og arbejdskraft ud over, hvad der opnås $i$ andre erhverv". Der identificeres to typer ressourcerente, før og efter at de offentlige nettoudgifter til flådesegmentet er fradraget. Ressourcerenten i et fiskeri angiver det ekstra overskud, der er tilbage, efter at arbejdskraft og kapital har opnået en aflønning på niveau med, hvad der opnås i andre erhverv, samt efter at den offentlige sektor har fået dækket sine nettoudgifter til fiskeriet. Ressourcerenten inkluderer også den rente, som de mest effektive fiskere opnår.

Aflønning af arbejdskraft og kapital i alternativ anvendelse fastsættes som det niveau, som realistisk vurderet, kan opnås. Der tages således ikke højde for, at det kan være nødvendigt at tilbyde fiskere en højere løn end i andre erhverv for at kunne opretholde rekrutteringen til fiskeriet. Der tages heller ikke højde for, at fiskeriet er et erhverv med overrepræsentation af arbejdsulykker og som foregår med flere ulemper, herunder med længerevarende fangstrejser under ikke altid lige bekvemme forhold. Dette forhold diskuteres i kapitel 5. Endvidere antages, at tilstedeværelsen af billig udenlandsk arbejdskraft opretholdes uændret.

Aflønning af kapital i alternativ anvendelse fastsættes på grundlag af, hvad der realistisk vurderes at kunne opnås såfremt den kapital, der er investeret i fiskefartøjer, investeredes i værdipapirer. Der tages således ikke højde for, at det kan være nødvendigt at opretholde en højere kapitalaflønning i fiskeriet, såfremt det er mere risikabelt at investere i fiskefartøjer.

\subsection{Ressourcerentens størrelse 2001-2003}

\subsubsection{Beregningsmetode}

Ressourcerente kan beregnes som:

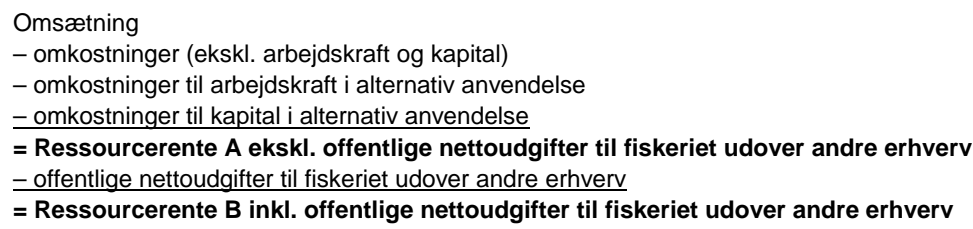

Ressourcerenten kan beregnes både uden fradrag af offentlige nettoudgifter til fiskeriet udover andre erhverv (type A), såvel som efter fradrag af disse nettoudgifter (type B). Ressourcerenten beregnes endvidere for 
flådesegmenter og inkluderer alene den rente, de betragtede flådesegmenter bidrager med. Ressourcerenten kan være både positiv og negativ. En positiv ressourcerente angiver, at der er et større overskud tilbage til aflønning af kapital og arbejdskraft i fiskeriet end i andre erhverv, hvor en negativ ressourcerente angiver, at der er mindre tilbage til aflønning af kapital og arbejdskraft end i andre erhverv.

Resultaterne i nærværende rapport er baseret på beregninger gennemført i case studierne.

Omsætningen inkluderer flådesegmentets samlede indtægter fra fiskeri og omkostninger udgøres af alt andet end til arbejdskraft og kapital. Dvs. alle omkostningstyper som er nødvendige for at gennemføre fiskeriet, herunder til brændstof, redskaber og afskrivninger. Både omsætning og omkostninger kendes fra offentliggjorte regnskabsstatistikker.

Omkostninger til arbejdskraft i alternativ anvendelse angiver, hvad de ansatte i flådesegmentet kan opnå i løn, såfremt de finder beskæftigelse i andre erhverv. I nærværende rapport beregnes denne løn for både officerer og menige fiskere og det antages at $30 \%$ af lønudgifterne går til officerer og $70 \%$ til menige fiskere ${ }^{2}$. Beregningen holder kun, såfremt fiskerne rent faktisk kan finde alternativ beskæftigelse. Såfremt den alternative beskæftigelse er begrænset, er omkostninger til arbejdskraft i alternativ anvendelse overvurderet og ressourcerenten undervurderet.

Omkostninger til kapital i alternativ anvendelse angiver, hvilken forrentning den kapital, der er investeret i fiskefartøjer, kan opnå, såfremt den blev investeret $\mathrm{i}$ andre kapitalgoder, $\mathrm{fx}$ aktier eller obligationer. I nærværende rapport beregnes den alternative forrentning på grundlag af fartøjernes forsikringsværdi, som antages at angive værdien af fartøjerne inkl. skrog, motor, redskaber mv. men ekskl. evt. fiskerirettigheder. Værdien af fiskerirettigheder behandles i nærværende rapport alene i forbindelse med fordeling af ressourcerenten, da disse ikke har betydning for størrelsen af den potientielle ressourcerente. Værdien af fiskerirettighederne har alene betydning for fordelingen mellem nuværende og tidligere ejere af fiskerirettigheder. Forrentningen baseres på Nationalbankernes rente på de længstløbende obligationer fratrukket inflation (realrenten) og tillagt samfundets vækstrate. Forrentningen antages at udgøre $6 \%{ }^{3}$. Med omkostninger til kapital i alternativ anvendelse baseret på fartøjernes forsikrings- og ikke på salgsværdien vil beregningen alene holde på lang sigt, såfremt forsikringsværdien er væsentligt højre end salgsværdien. Dette kan være tilfældet i fiskerier med overkapacitet.

\footnotetext{
${ }^{2}$ Aflønningen af arbejdskraft i alternativ anvendelse beregnes forskelligt i de fem lande. For Island og Norge anvendes et gennemsnit af lønnen i alle erhverv for både officerer og menige fiskere. For Færøerne og Sverige skelnes mellem løn til faglærte og ufaglærte i industrien og for Danmark skelnes mellem en kort videregående uddannet og en faglært $\mathrm{i}$ industrien.

${ }^{3}$ For Danmark er Nationalbankens rente på de længst løbende statsobligationer i 2005 3,7 \% og inflationen 1,7 \%. Realrenten bliver således $2 \%$. Denne tillægges samfundets vækstrate på 3,5 \% hvorved forrentningen bliver 5,5\%, som oprundes til $6 \%$. Forrentningen antages med udgangspunkt $i$ at kapitalmarkederne er internationale at være den samme i de øvrige lande.
} 
Offentlige nettoudgifter til fiskeriet udover andre erhverv angiver de offentlige udgifter til fiskerisektoren fratrukket brugerbetaling fra fiskeriet, samt fratrukket de offentlige udgifter til andre erhverv. Offentlige udgifter til fiskerisektoren udgøres i nærværende rapport alene af offentlige udgifter til fiskefartøjer. Dette er offentlige tilskud, herunder til ophør, ophugning, fornyelse, modernisering, omkostnings-reducerende transfereringer og i Færøerne indkomststøtte til fiskere. Offentlige udgifter inkluderer også fiskeriforvaltningsomkostninger, herunder fx omkostninger til kontrol, biologiske undersøgelser og rådgivning. De offentlige udgifter kendes alene for hele fiskerisektoren i de respektive fem lande og er derfor fordelt på de udvalgte fiskerier med disse fiskeriers andel af den samlede fangstværdi. Brugerbetaling eksisterer alene i Island og udgøres af opkrævning af visse typer kontrolomkostninger. ${ }^{4}$ Offentlige udgifter til andre erhverv kendes ikke og er derfor ikke inddraget i beregningen. Dette indebærer, at ressourcerenten efter fradrag af offentlige nettoudgifter til fiskeriet udover andre erhverv (type B) er undervurderet.

Beregningen af ressourcerenten baseres på en række beregningsforudsætninger for de enkelte poster, som indebærer, at resultaterne er behæftet med betydelig usikkerhed. Konsekvensen er, at resultaterne skal fortolkes med forsigtighed.

\subsubsection{Data}

Data fra fire af de fem case studier er fra 2001-2003, data for det norske kystfiskeri er fra 2003-2004, idet der i 2003 blev introduceret nye flådesegmenter i statistikken. Nødvendige data inkluderer regnskabsstatistik, statistik over alternativ aflønning af arbejdskraft og kapital, samt statistik over offentlige udgifter til fiskeriet. Der eksisterer national regnskabsstatistik for flådesegmenterne $\mathrm{i}$ fire af landene med kilder angivet $\mathrm{i}$ case studie rapporterne. Regnskabsstatistik for partrawlerfiskeriet i Færøerne kendes fra Rasmussen og Weihe (2005). Aflønning af arbejdskraft og kapital i andre erhverv end fiskeriet kendes fra de nationale statistikkontorers løn og kapitalmarkedsstatistik. Offentlige udgifter til fiskeriet kendes fra fire lande fra OECD $(2004,2005)$. Tal fra Færøerne stammer fra Færøernes Landsbank.

\subsubsection{Resultater}

Ressourcerentens størrelse som årligt gennemsnit over 2001-2003 er angivet for de fem udvalgte fiskerier i tabel 3 før fradrag af offentlige nettoudgifter til fiskeriet.

\footnotetext{
${ }^{4}$ Brugerbetaling inkluderer betaling for køb af fiskerirettigheder hos den offentlige sektor, f.eks. ved køb på auktion. Køb af fiskerirettigheder af andre fiskere er ikke inkluderet.
} 
Tabel 3. Størrelsen af ressourcerenten 2001-2003 (type A), mio. DKK og pct. af fangstværdi.

\begin{tabular}{lrrrrr}
\hline & Island & Norge & Færøerne & Sverige & Danmark \\
\hline Aflønning af kapital & 336 & 40 & 53 & 80 & 59 \\
Aflønning af arbejdskraft & 1.092 & 422 & 123 & 89 & 55 \\
Aflønning af ressourcen & $\underline{0}$ & $\underline{2}$ & $\underline{0}$ & $\underline{0}$ & $\underline{0}$ \\
\hline Total (I) & 1.428 & 464 & 176 & 169 & 114 \\
Aflønning af kapital i alternativ anvendelse & 158 & 135 & 33 & 65 & 7 \\
Aflønning af arbejdskraft i alternativ anvendelse & $\underline{505}$ & $\underline{505}$ & $\underline{59}$ & $\underline{92}$ & $\underline{27}$ \\
Total (II) & 663 & 640 & 92 & 157 & 34 \\
Ressourcerenten (=I-II) & 765 & -176 & 84 & 12 & 80 \\
$\quad-$ pct. af fangstværdi & $30 \%$ & $-22 \%$ & $28 \%$ & $3 \%$ & $60 \%$ \\
\hline
\end{tabular}

Kilder: Nødvendige data for at udarbejde denne tabel er angivet i rapporten „Focus on the economy of the Nordic fisheries - case study reports from Iceland, Norway, the Faroe Islands, Sweden and Denmark".

I tabellen er angivet den faktiske aflønning af kapital, arbejdskraft og ressource, fratrukket aflønningen af kapital og arbejdskraft i alternativ anvendelse. Forskellen er ressourcerenten (type A). Aflønningen af ressourcen er beskatning på 0,2 \% af landingsværdien i Norge.

Ressourcerenten er med 765 mio. DKK størst i det islandske trawlerfiskeri, på niveau i det færøske partrawlerfiskeri og det danske muslingefiskeri (hhv. 84 og 80 mio. DKK), 12 mio. DKK i det svenske stimefiskeri og minus 176 mio. DKK i det norske kystfiskeri ${ }^{5}$.

Målt i forhold til landingsværdien er ressourcerenten med $60 \%$ størst i det danske muslingefiskeri, på niveau i Island og i Færøerne (hhv. 30 \% og $28 \%$ ), 3 \% i Sverige og minus $22 \%$ i Norge.

Resultaterne angiver, at ressourcerenten er størst i det danske muslingefiskeri, hvilket hænger samme med en restriktiv licens- og kapacitetsregulering, hvor tilgangen af fartøjer i flere årtier har været beskedent. Også periodelukninger og kvoter har medført, at bestandenes tilstande er positive, hvilket igen er vigtigt for de gode økonomiske resultater. I sammenligning med de øvrige fire fiskerier hænger den ekstraordinært gode økonomi i det danske muslingefiskeri sammen med, at omkostninger ved fiskeriet er lave, da bestandene er stationære, samtidig med at der ikke i fiskeriet er væsentlig overkapacitet.

Resultaterne for det islandske trawlerfiskeri og det færøske partrawlerfiskeri angiver, at forvaltningen med hhv. individuelt omsættelige kvoter og havdage formår at generere forholdsvis store ressourcerenter. Det færøske resultat skal dog også ses i sammenhæng med, at perioden 20012003 biologisk var gode år med ekstraordinær stor rekruttering af fisk (i den alder de kan fiskes) set i forhold til den foregående femårsperiode. Hvor den islandske ressourcerenten primært kan forklares på grundlag af den strukturelle økonomiske udvikling i fiskeriet over en årrække, kan

\footnotetext{
${ }^{5}$ Beregningen af aflønning af kapital i alternativ anvendelse, som indgår i grundlaget for den identificerede ressourcerenten i det norske kystfiskeri, er væsentlig forskellig fra de tal der er angivet i rapporten „Focus on the economy of the Nordic fisheries - case study reports from Iceland, Norway, the Faroe Island, Sweden and Denmark“. Forskellen består i, at der i det norske case studie regnes med en lavere forrentning end i nærværende rapport.
} 
den færøske primært forklares ved gunstige biologiske forhold i den analyserede periode.

I Sverige skal den beskedne ressourcerente fortolkes i forhold til en økonomisk mindre effektiv forvaltning ved rationer, som i en kortere periode, fx to uger, giver adgang til at fiske en givet mængde. Når mængden er opfisket, skal fiskeriet stoppes. Dette indebærer i et fiskeri med overkapacitet, at omkostningerne er væsentlige, uden der er mulighed for at udnytte kapitalapparatet optimalt. Konsekvensen er, at ressourcerenten er tæt på nul.

Den negative ressourcerente i det norske kystfiskeri opstår som følge af, at fiskeriet er sæsonbetonet, hvorfor fartøjerne kun kan udnyttes effektivt en del af året. Endvidere er det af betydning, at der fiskes på bestande der er fælles med Rusland, hvor der foregår et betydeligt overfiskeri og hvor, den alternative aflønning af arbejdskraft er relativt høj samtidig med at der tages regionalpolitiske og beskæftigelsesmæssige hensyn i fiskeriforvaltningen. Lønniveauet er således lavere i fiskeriet end i andre erhverv, hvilket bl.a. kan forklares ved, at nogle fiskere finder det mere attraktivt at arbejde på havet end i land.

Ovenstående ressourcerenter er beregnet uden fradrag af offentlige nettoudgifter til fiskeriet (som type A). I tabel 4 er tilsvarende tal angivet efter fradrag de af offentlige nettoudgifter (som type B).

Tabel 4. Størrelsen af ressourcerenten 2001-2003 (type B), mio. DKK og pct. af fangstværdi.

\begin{tabular}{|c|c|c|c|c|c|}
\hline & Island & Norge & Færøerne & Sverige & Danmark \\
\hline Ressourcerente (type A) & 765 & -176 & 84 & 12 & 80 \\
\hline \multicolumn{6}{|l|}{ Offentlige nettoudgifter ${ }^{1}:$} \\
\hline Tilskud & 0 & -9 & -5 & -26 & -8 \\
\hline Fiskeriforvaltningsomkostninger & -90 & -84 & -20 & -66 & ${ }^{2}-14$ \\
\hline Brugerbetaling for kontrol & $\underline{41}$ & $\underline{0}$ & $\underline{0}$ & $\underline{0}$ & $\underline{0}$ \\
\hline Total & $-\overline{49}$ & $-9 \overline{3}$ & $-2 \overline{5}$ & $-9 \overline{2}$ & $-2 \overline{2}$ \\
\hline - pct. af fangstværdi & $2 \%$ & $12 \%$ & $8 \%$ & $23 \%$ & $17 \%$ \\
\hline Ressourcerente (type B) & 716 & -269 & 59 & -80 & 58 \\
\hline - pct. af fangstværdi & $28 \%$ & $-34 \%$ & $20 \%$ & $-20 \%$ & $44 \%$ \\
\hline
\end{tabular}

Note: 1. De angivne udgifter er landets samlede offentlige udgifter til fiskeriet vægtet med flådesegmentets andel af de samlede landinger.

2. Fiskeriforvaltningsomkostninger i Danmark er estimerede på grundlag af flådesegmentets andel af de totale omkostninger i EU.

Kilder: OECD $(2004,2005)$ og Færøernes Landsbank (2006).

De offentlige nettoudgifter til fiskerisektoren består af tilskud og fiskeriforvaltningsomkostninger. Tilskud udgør årligt fra ingenting i Island til 26 mio. DKK i Sverige, idet det dog bemærkes, at de svenske tal kan være overvurderede. Årsagen er, at det ikke har været muligt at udskille visse tilskudsformer, eksempelvis til havne. De øvrige er i størrelsesordenen 8-9 mio. DKK. Omkostninger til fiskeriforvaltning udgør fra 14 mio. DKK i Danmark til 90 mio. DKK i Island. For Danmark er omkostningerne skønnede på grundlag af EU gennemsnittet og derved behæftet med ekstra usikkerhed. I Norge, Sverige og Færøerne udgør omkostningerne 
til fiskeriforvaltning hhv. 84, 66 og 25 mio. DKK. Fiskeriforvaltningsomkostningerne er således i alle lande væsentligt højere end tilskuddene i de fem lande. Fiskeriforvaltningsomkostningerne udgør derfor kernen i de offentlige udgifter til den primære fiskerisektor.

I Færøerne er beregningerne af type B ressourcerenten baseret på, at offentlige nettoudgifter til flådesegmentet er fordelt ud fra fordelingen af fiskeriet i nationalt farvand. Baseres beregningen i stedet på, at fiskeriets nettoudgifter er fordelt ud fra den totale fangstfordeling inkl. fangster i fjernfiskeriet, bliver ressourcerenten efter fradrag af offentlige nettoudgifter til fiskeriet 68 mio. DKK eller $23 \%$. Det vurderes at den reelle type B ressourcerente ligger et sted imellem de 20 og $23 \%$, da offentlige udgifter til både kontrol og biologiske undersøgelser vurderes at være større i de nære end i de fjerne farvande.

I Island opkræves 41 af de 90 mio. DKK i fiskeriforvaltningsomkostninger i form af brugerbetaling for visse typer af kontrolomkostninger.

De offentlige nettoudgifter udgør fra $2 \%$ af landingsværdien i Island til $23 \%$ i Sverige. Fiskeriforvaltningsomkostningerne i Norge og i Færøerne er på hhv. 12 \% og 8 \%. I Danmark udgør de $17 \%$. Der er således væsentlig forskel mellem landene. Omkostningerne er størst i EU landene (Danmark og Sverige) som er underlagt den fælles fiskeripolitik. Omkostningerne er lavest i Island, dels som følge af at visse kontrolomkostninger opkræves, dels som følge af at den automatiske strukturtilpasning, der er en konsekvens af det individuelt omsættelige kvotesystem, kan begrænse overkapacitet og derigennem behovet for kontrol.

Ressourcerenten efter fradrag af offentlige nettoudgifter til fiskeriet forbliver med 716 mio. DKK størst i det islandske trawlerfiskeri og nogenlunde på niveau i det færøske partrawlerfiskeri og det danske muslingefiskeri (hhv. 59 og 58 mio. DKK). I Norge vedbliver ressourcerenten med at være negativ, og faldert fra minus 176 til 269 mio. DKK. Den største ændring ses i Sverige, hvor ressourcerenten, som følge af tilstedeværelsen af de store offentlige nettoudgifter til fiskeriet, ændrer sig fra at være 12 til at blive minus 80 mio. DKK.

Målt i forhold til landingsværdien er ressourcerenten efter fradrag af offentlige nettoudgifter stadig størst i Danmark (44 \%), Island (28 \%) og i Færøerne (20\%). I Norge og Sverige er ressourcerenten nu negativ med hhv. $34 \%$ og $20 \%$ af landingsværdien ${ }^{6}$.

Ovenstående resultater er beregnet som det årlige gennemsnit for perioden 2001-2003. Disse år kan imidlertid have været ekstraordinært

\footnotetext{
${ }^{6}$ Resultaterne kan sammenlignes med beregninger af ressourcerenten hvor, der foreligger andre undersøgelser. Disse er få, men der er foretaget beregninger for Norge og Island. I Norge beregner Steinshamn (2005) ressourcerenten i de norske helårsdrevne fiskerier og opnår en total ressourcerente på 136 mio. NOK ved en alternativ forrentning af kapitalen på 7 \%. Dette svarer til 1 \% af landingsværdien. Indenfor flådesegmentet 8-13 meter vurderes ressourcerenten at være negativ på 99 mio. NOK, hvilket svarer til 14 \% af landingsværdien. I Island beregner Gudmundsson et al (2001) ressourcerenten i det islandske trawlerfiskeri i 1995-2000 til 7-21 \% af landingsværdien. Resultaterne i dette studie er således i god overensstemmelse med tidligere undersøgelser på trods af, at der er anvendt forskellige beregningsmetoder.
} 
gode eller dårlige, hvorfor det i tabel 5 vurderes om vigtige faktorer, som er bestemmende for ressourcerentens størrelse, er mere eller mindre gunstige end den foregående fem års periode. Fangsterne bestemmes af fiskerireguleringen som igen fastsættes på grundlag af bestandenes tilstand, fiskeritryk og rekruttering af fisk (af de årgange der fiskes på). Priserne som bestemmes af eksterne forhold, som normalt er udenfor flådesegmentets kontrol, er også afgørende for ressourcerentens størrelse.

Tabel 5. Faktorer der kan medvirke til at forklare om der er en høj ressourcerente.

\begin{tabular}{lrrrrr}
\hline & Island & Norge & Færøerne & Sverige & Danmark \\
\hline Rekruttering (udvikling 01-03 fra 96-00, pct.) & -9 & +4 & +81 & -5 & -38 \\
Prispræmie (i 01-03 over 96-00, pct.) & & & & & \\
& +25 & +30 & +2 & +39 & +47 \\
Bestandenes udnyttelsesgrad (\%) & & & & & \\
Under & 0 & 7 & 0 & 0 & 0 \\
Fuldt & 4 & 60 & 34 & 48 & 74 \\
Over & 38 & 0 & 52 & 44 & 0 \\
Nedfisket eller under genopretning & 7 & 0 & 0 & 8 & 0 \\
Ukendt & $\underline{51}$ & $\underline{33}$ & $\underline{14}$ & $\underline{0}$ & $\underline{26}$ \\
Total & 100 & 100 & 100 & 100 & 100 \\
\hline
\end{tabular}

Noter: 1. Angiver gennemsnitlig rekruttering af de vigtigste årgange, der fiskes på i den analyserede 3-årsperiode. Denne sammenlignes med et gennemsnit af de foregående fem år. Rekrutteringen er vægtet med landingsværdien og beregnes alene for bestande, for hvilke rekrutteringen løbende vurderes. For øvrige bestande forudsættes rekrutteringen uændret, hvorved udviklingen i rekrutteringen bliver konservativt vurderet. For Island indgår kun torsk og kuller, svarende til $45 \%$ af landingsværdien. Rekrutteringen opgøres ikke i det danske muslingefiskeri, hvorfor udviklingen i biomassen fremgår. 2. Gennemsnitlige priser for de vigtigste arter der fiskes på, beregnet for 3-årsperioden vægtet med fangstværdien og sammenlignet med et gennemsnit af de foregående fem år. Prisudviklingen er angivet i løbende priser og beregnes alene for fiskearter, som er medtaget som kendte under biologiske faktorer.

Kilder: Nødvendige data for at udarbejde denne tabel er angivet i rapporten „Focus on the economy of the Nordic fisheries - case study reports from Iceland, Norway, the Faroe Islands, Sweden and Denmark".

Rekrutteringen af fisk i Færøerne var væsentligt højere i 2001-2003 end i den foregående femårsperiode. I Norge og Sverige var rekrutteringen nogenlunde konstant med hhv. en stigning på $4 \%$ og et fald på $5 \%$. I Island faldt rekrutteringen $9 \%$, hvor den faldt hele $38 \%$ i det danske muslingefiskeri målt i forhold til biomassen. Rekrutteringsudviklingen afspejler således at 2001-2003 i biologisk henseende var gennemsnitsår i Norge, Sverige og Island. I Færøerne var årene meget gunstige i forhold til tidligere, hvor de i Danmark var ugunstige.

Af tabellen fremgår endvidere udviklingen i priserne på fisk for 20012003 i forhold til den foregående femårsperiode. Prisudviklingen vurderes således at være den vigtigste faktor, der kan medvirke til at forøge eller reducere ressourcerenten. Priserne er for alle fem flådesegmenter stigende, med $47 \%$ mest i det danske muslingefiskeri og med $2 \%$ mindst i det færøske partrawlerfiskeri. Også i Sverige, Norge og Island er prisstigningerne betydelige med hhv. $39 \%$, $30 \%$ og $25 \%$. Dette skal sammenlignes med at prisniveauet i EU, hvor størstedelen af fisk fra de fem fiskerier afsættes, steg med 8 \% mellem de to perioder (fra 1998 til 2002). De reale priser stiger således i alle lande, bortset fra i Færøerne, hvor prisen på fisk stiger mindre end prisen på andre varer. Der er en lang række årsager til disse prisstigninger, som afspejler, at fisk og fiskeprodukter sælges på et verdensmarked. Faldende udbud af fiskearter som fx 
torsk, kombineret med stigende global efterspørgsel, samt udviklingen i $€-\$$ valutakursen kan medvirke til at forklare de stigende priser. En årsag til at priserne ikke stiger mere for de færøske partrawlere er, at den vigtigste art er sej, som afsættes på EU markedet i stadig større konkurrence med Alaskasej fra USA og Rusland.

Endelig fremgår bestandenes udnyttelsesgrad af tabellen. Disse er subjektivt vurderet på grundlag af ICES rådgivning om fiskeridødelighedsniveau og gydebiomasse ${ }^{7}$. Bestandenes udnyttelsesgrad angiver hvor stor en del af landingsværdien, der er hhv. underudnyttet, fuldt udnyttet, overudnyttet, nedfisket eller under genopretning. Således angiver fx de $74 \%$ for Danmark, at $74 \%$ af landingsværdien fra det danske muslingefiskeri stammer fra bestande, der er fuldt udnyttede. Bestandenes udnyttelsesgrad er et mål for, om fiskeriet er bæredygtigt på lang sigt. Såfremt bestandene er underudnyttet eller fuldt udnyttet, er fiskeriet bæredygtigt og den ressourcerente, der blev opnået i 2001-2003, skønnes realistiske også i fremtiden. Såfremt bestandene er overudnyttede, er fiskeriet ikke bæredygtigt og der er risiko for at ressourcerenten, som blev opnået i 20012003, vil falde.

Udnyttelsesgraderne er ukendte i flere tilfælde. Dette skyldes, at der ikke udarbejdes biologiske undersøgelser for en række fiskearter eller at udarbejdede undersøgelser ikke har den tilstrækkelige sikkerhed. Dette gælder eksempelvis for $51 \%$ af fangstværdien i det islandske trawlerfiskeri, hvor der bl.a. ikke udarbejdes egentlige undersøgelser for det vigtige rødfiskefiskeri. For Danmark gælder det eksempelvis muslingefiskeri i Vadehavet. I Norge skyldes de 33 \% ukendt, at der i kystfiskeriet fiskes på en lang række forskellige arter, hvor der ikke foretages biologiske undersøgelser på alle.

Udnyttelsen er i Norge og Danmark i alle kendte tilfælde bæredygtig, hvor udnyttelsen er bæredygtig i Sverige i 48 \%, i Færøerne i 34 \% og i Island i $4 \%$ af tilfældene. I Færøerne, Sverige og Island er der overudnyttelse i hhv. $52 \%, 40 \%$ og $38 \%$. Dette indebærer at den ressourcerente, der opnåedes i 2001-2003 i Norge og Danmark, også realistisk kan forventes opretholdt fremover. I Sverige, Færøerne og Island er der risiko for, at ressourcerenten vil falde.

På grundlag af ovenstående har perioden 2001-2003 sammenlignet med den foregående femårsperiode været nogenlunde „normale“ år for Sverige, Norge og Island. Rekrutteringen er nogenlunde konstant og priserne på fisk stiger lidt mere end andre varer. I Island er priserne målt $\mathrm{i}$ islandsk valuta i 2001-2003 dog under niveauet i den foregående femårsperiode, som følge af at den islandske krone var svag. Perioden 2001-

\footnotetext{
${ }^{7}$ Der er underudnyttelse, hvis gydebiomassen er større og fiskeridødeligheden mindre end angivet af forsigtighedsprincippet. Bestanden er nedfisket eller under genopretning, hvis gydebiomassen er mindre end grænseværdien for forsigtighedsprincippet og fiskeridødeligheden større end grænseværdien (limit value). Der er overudnyttelse, hvis gydebiomassen er større end angivet af forsigtighedsprincippet og fiskeridødeligheden større end grænseværdien. I alle andre tilfælde er der fuld udnyttelse. Denne metode anvendes med udgangspunkt i Nordisk Ministerråd (2000).
} 
2003 kan således have været lidt under det „normale“ i Island. I Danmark falder rekrutteringen væsentligt, men dette imødegås af stigende priser. I Færøerne stiger priserne mindre end på andre varer, men dette imødegås af forøget rekruttering. For alle fem lande er 2001-2003 således nogenlunde „normale“. Baseret på bestandenes udnyttelsesgrader, vurderes ressourcerenten, at kunne opretholdes fremover i Danmark og Norge, hvor der i de øvrige lande er risiko for, at den falder.

\subsection{Den maksimale ressourcerente}

Den maksimale ressourcerente er defineret som „det årlige maksimale overskud der på lang sigt er tilbage efter aflønning af kapital og arbejdskraft svarende til, hvad der opnås i andre erhverv". Den maksimale ressourcerente angiver således det ekstra overskud, der hvert år ud i al fremtid er tilbage efter, at arbejdskraft og kapital har opnået en aflønning på niveau med, hvad der opnås i andre erhverv. Den maksimale ressourcerente identificeres af type A, dvs. før fradrag af offentlige nettoudgifter til fiskeriet.

En stor ressourcerente er ud fra en snæver langsigtet økonomisk betragtning ønskelig, men størrelsen af ressourcerenten skal ses i sammenhæng de generelle fiskeripolitiske målsætninger relateret til beskæftigelse, regionalpolitik og flådestruktur. Normalt vil det ikke være muligt, at opnå den maksimale ressourcerente uden at beskæftigelsen falder. Det er heller ikke nødvendigvis muligt samtidigt at opnå den maksimale ressourcerente og et bestemt regionalt bosætningsmønster, såvel som det ikke nødvendigvis er muligt at opnå den maksimale ressourcerente samtidig med tilstedeværelsen af en bestemt flådestruktur, eksempelvis med plads til kystfiskeri. Opnåelse af den maksimale ressourcerente er således et fiskeripolitisk mål, der skal prioriteres i sammenhæng med de øvrige fiskerpolitiske målsætninger. I nærværende afsnit vurderes ikke, hvilke politiske målsætninger der bør prioriteres, der beregnes alene, hvor stor en ressourcerente der kan opnås, såfremt der føres en fiskeripolitik, der alene tilstræber at opnå den maksimale ressourcerente og som ikke tager hensyn til, at der også er andre mål i fiskeripolitikken.

Den maksimale ressourcerente er endvidere pr. definition beregnet som holdbar på lang sigt, men opnåelse af den maksimale ressourcerente på lang sigt vil typisk indebære, at der skal gives noget op på kort sigt. Dette forhold inddrages ikke i nærværende afsnit. Den maksimale ressourcerente identificeres på lang sigt, det overvejes ikke, hvordan man kommer fra den nuværende situation til en situation, hvor den maksimale ressourcerente er opnået. Identifikationen af den maksimale ressourcerente er således alene en angivelse af det økonomiske potentiale i de nordiske fiskerier. Opnåelse af den maksimale ressourcerente forudsætter, at 
der gives afkald på andre områder, som ikke gennemgås detaljeret i nærværende rapport.

\subsubsection{Beregningsmetode}

Den maksimale ressourcerente beregnes i en bio-økonomisk model på grundlag af en lang række simplificerende forudsætninger. Dette indebærer, at der er stor usikkerhed på beregningerne. Den maksimale ressourcerente giver en indikation af det økonomiske potentiale, men kan ikke beregnes præcist. Det tekniske grundlag for modellen er gennemgået i bilaget.

Ideen i beregningen er, at den maksimale ressourcerente bestemmes ved den fiskeriindsats, målt ved antal havdage, som giver den største forskel mellem omsætning og omkostninger. Omsætningen bestemmes, med de konstante priser, af fangsterne som på lang sigt stiger med fiskeriindsatsen indtil et vist niveau, hvorefter de falder. Årsagen til faldet er, at fiskes der tilstrækkeligt meget, vil der opstå overfiskeri, hvor det på lang sigt ikke er muligt at opretholde samme fangstniveau. Omkostningerne stiger med fiskeriindsatsen, idet det er dyrere at fiske jo mere der fiskes. Det antal fartøjer, der er nødvendige for at opnå den maksimale ressourcerente, findes ud fra det totale antal havdage, givet at store fartøjer udnyttes 300 dage om året og små fartøjer 225 dage om året. Islandske, færøske og svenske fartøjer er store, hvor danske og norske er små. Årsagen til at små fartøjer „kun“ udnyttes 225 dage om året er bl.a. vejret og, at der ikke i samme omfang som for store fartøjer, er skiftende besætninger. Det norske kystfiskeri er endvidere sæsonbetonet som følge af tilstedeværelsen af fisken, hvor det danske muslingefiskeri ligger stille i perioder, hvor for varmt vand kan skabe kvalitetsproblemer. Ideen i beregningen er skitseret grafisk i nedenstående boks.

\section{Bestemmelse af den maksimale ressourcerente.}

Den maksimale ressourcerente bestemmes, hvor forskellen mellem indtægter og omkostninger i fiskeriet ved en bestemt fiskeriindsats er størst. Fiskeriindsatsen måles ved det totale antal havdage i flådesegmentet om året.

Omsætningen er stigende med stigende fiskeriindsats, idet der fanges mere jo mere der fiskes, så længe bestanden ikke overfiskes. Stiger fiskeriindsatsen tilstrækkeligt meget, vil fangsterne falde. Årsagen er, at fiskebestandene ikke har tid til at genetablere sig efter intensivt fiskeri, hvilket medfører, at omsætningen falder.

De totale omkostninger er stigende med stigende fiskeriindsats, idet det er dyrere at fiske jo flere fartøjer og dermed havdage, der anvendes. Samtidig er de gennemsnitlige omkostninger stigende med stigende fiskeriindsats bl.a. som følge af, at nogle fiskere er mere effektive end andre. 
Fortsat fra foregående side

Den eksisterende ressourcerente er i figuren angivet som $\mathrm{R}_{0}$, hvor den større maksimale ressourcerente er angivet, der hvor forskellen mellem total omsætning og totale omkostninger er størst $\left(R_{\max }\right)$.

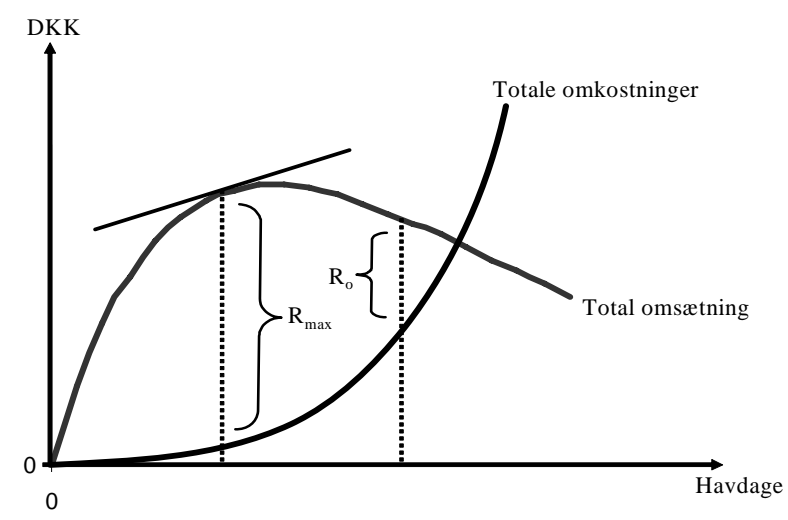

Beregningen baseres på en bio-økonomisk model som er en revideret version af EIAA modellen (SEC 2004). EIAA står for Economic Interpretation of ACFM Advice og modellen anvendes til vurdering af de økonomiske konsekvenser af at gennemføre det Internationale Havforskningsråds biologiske rådgivning i den årlige kvotefastsættelse i EU. Ideen i modellen er, at anvende biologiske bestands- og kvoteestimater i samspil med økonomiske informationer på variable og faste omkostninger. Med givne fangstmuligheder og bestandsstørrelser beregner modellen de lavest mulige omkostninger for at fange den givne mængde. Herigennem bestemmes overskud og ressourcerente.

EIAA modellen anvendes normalt primært for det korte sigt til vurdering af næste års kvoter, hvor beregningen af den maksimale ressourcerente i nærværende afsnit er for det lange sigt. Derfor har det været nødvendigt at udvide modellen på nogle områder. For det første er biologi inddraget mere eksplicit ved at størrelsen af gydebiomassen bestemmer fangsterne på lang sigt og under antagelse af at fiskeridødeligheden i udgangssituationen er bæredygtig. Ressourcerenten, beregnet i denne model, fortolkes så efterfølgende i forhold til denne antagelse. Er antagelsen realistisk er beregningen af ressourcerentens størrelse rimelig. Er fiskeridødeligheden i udgangssituationen derimod ikke bæredygtig, er der risiko for fremtidige reduktioner i rekruttering og bestand, hvilket kan indebære, at ressourcerenten på lang sigt vil falde. For det andet er omkostningsberegningen baseret på, at alle omkostninger er variable, hvilket er nødvendigt, da modellen analyserer det lange sigt. For det tredje afhænger omkostningerne alene af fiskeriindsatsen, da der herigennem opstår mulighed for at indbygge i modellen, at nogle fiskere er mere ef- 
fektive end andre eller har lavere alternative beskæftigelses- og indtægtsmuligheder.

Beregningen baseres på en lang række simplificerende forudsætninger som teknisk er gennemgået i bilaget. Disse er:

1. Uændret flådestruktur.

2. Uændret fiskerimønster.

3. Den gydebiomasse, der giver de størst mulige vedvarende fangster, bestemmes ved forsigtighedsprincippet.

4. Fiskeridødeligheden i dag er bæredygtig.

5. Bestandssituationen for bestande, hvor biologiske informationer er mangelfulde, følger situationen i bestande, hvor biologien er kendt

6. Den maksimale kapacitetsudnyttelse er 300 dage i Island, Færøerne og Sverige og 225 dage i Norge og Danmark.

7. Mulighed for alternativ beskæftigelse foreligger.

8. Prisen på fisk er konstant

Uændret flådestruktur indebærer at den størrelse og type fartøjer, der er i dag, skal der være plads til ud i al fremtid, hvor uændret fiskerimønster indebærer, at de enkelte flådesegmenters fiskeri på forskellige bestande er uafhængigt af hinanden, såvel som de enkelte flådesegmenters relative tidsforbrug på de forskellige bestande er konstant. Den gydebiomasse, der giver de største vedvarende fangster, bestemmes ved forsigtighedsprincippet i alle lande ekskl. Island, hvor princippet ikke bruges i den biologiske rådgivning. For Island anvendes et gennemsnit af de sidste ti år. Den konstante pris på fisk indebærer, at ændret udbud ikke påvirker prisen, hvilket vurderes rimeligt, da priser på de fleste fiskearter dannes på verdensmarkedet. Beregningen baseres alene på viden om de bestande, der haves biologiske vurderinger af. Andelen disse omfatter af flådesegmenternes samlede fangster er angivet i tabel 5 . Resultaterne er mere pålidelige jo mindre den ukendte udnyttelsesgrad er. Den konstante pris indebærer endvidere, at der i beregningen ses bort fra, at bedre fiskeriforvaltning kan medføre, at udbudet stiger og priserne derved falder. Antagelsen om at prisen er uafhængig af udbudet i det konkrete fiskeri vurderes dog realistisk, idet priserne på de fleste arter bestemmes på et verdensmarked ${ }^{8}$. Den konstante pris indebærer også, at der ses bort fra, at bedre fiskeriforvaltning kan medføre, at der fanges større fisk, som normalt giver højere kilopris. Forudsætningen for at muligheden for alternativ beskæftigelse forelægger indebærer, at fiskere til enhver tid kan finde andet arbejde på land svarende til gennemsnitslønnen.

Biologien inddrages i beregningen gennem den gydebiomasse, som giver det største biologiske udbytte (MSY) på lang sigt. Denne antages bestemt af forsigtighedsprincippet. Herudover inddrages biologien gen-

\footnotetext{
${ }^{8}$ En undtagelse er dog kuller landet i Island hvor erfaringer viser, at forøget udbud har givet lavere pris.
} 
nem antagelse af, at fiskeridødeligheden er bæredygtig, hvor den beregnede ressourcerente fortolkes i forhold til rimeligheden af denne antagelse. Er antagelsen rimelig er ressourcerenten realistisk, ellers er der risiko for, at den er overvurderet på lang sigt. Ses eksempelvis på torsk i Norge er gydebiomasse 642.000 tons (2003), hvor den gydebiomasse, der skaber det størst mulige langsigtede fangst, er 460.000 tons. Dette indebærer, at gydebiomasssen er på et bæredygtigt niveau. Derimod er fiskeridødeligheden højere end intentionen i forvaltningsplanen (ICES 2003), hvilket indebærer, at der er forøget risiko for rekrutteringssvigt. Konsekvensen er risiko for, at den beregnede maksimale ressourcerente er overvurderet.

Økonomi inddrages i beregningen, som beskrevet i afsnit 4.1.1, tilføjet antagelsen af konstante priser og at totale omkostninger stiger med fiskeriindsatsen.

\subsubsection{Data}

Økonomiske data er beskrevet $\mathrm{i}$ afsnit 4.1.2. Biologiske data kendes fra det Internationale Havforskningsråd (ICES), som årligt rådgiver om fiskeriforvaltningen for de vigtigste bestande i det nordøstlige Atlanterhav. Herudover anvendes også de biologiske data, som ligger til grund for EU kommissionens rådgivende tekniske, videnskabelige og økonomiske komité (STECF) for fiskeri, der rådgiver EU kommissionen om fiskeriforvaltningen. For det danske muslingefiskeri anvendes årlige bestandsvurderinger foretaget af Danmarks Fiskeriundersøgelser. De biologiske data, der anvendes, er faktisk gydebiomasse og den gydebiomasse, der giver de maksimale vedvarende fangster, samt faktiske fangster. Den gydebiomasse, der giver de størst mulige fangster på lang sigt, bestemmes af forsigtighedsprincippet. ICES fastsætter, ved anvendelse af dette princip, årligt det niveau for gydebiomassen, der giver den størst mulige sikkerhed for fremtidig fangster. Gydebiomassen i bestandene i de fem udvalgte fiskerier er angivet i tabel 6. I Island anvendes forsigtighedsprincippet ikke, hvorfor den gydebiomasse, der giver de størst mulige vedvarende fangster, er fastsat som det gennemsnitlige niveau de sidste ti år.

Det fremgår, at gydebiomasserne for bestandene i det islandske, færøske (ekskl. sej), danske og norske fiskeri i alle tilfælde har fuld reproduktionskapacitet. For Sverige er dette kun tilfældet for sild i Vestkyst fiskeriet, samt for blåhvilling. For de øvrige bestande er reproduktionskapaciteten reduceret. 
Tabel 6. Faktisk gydebiomasse og de gydebiomasser der giver de største vedvarende fangster, tons.

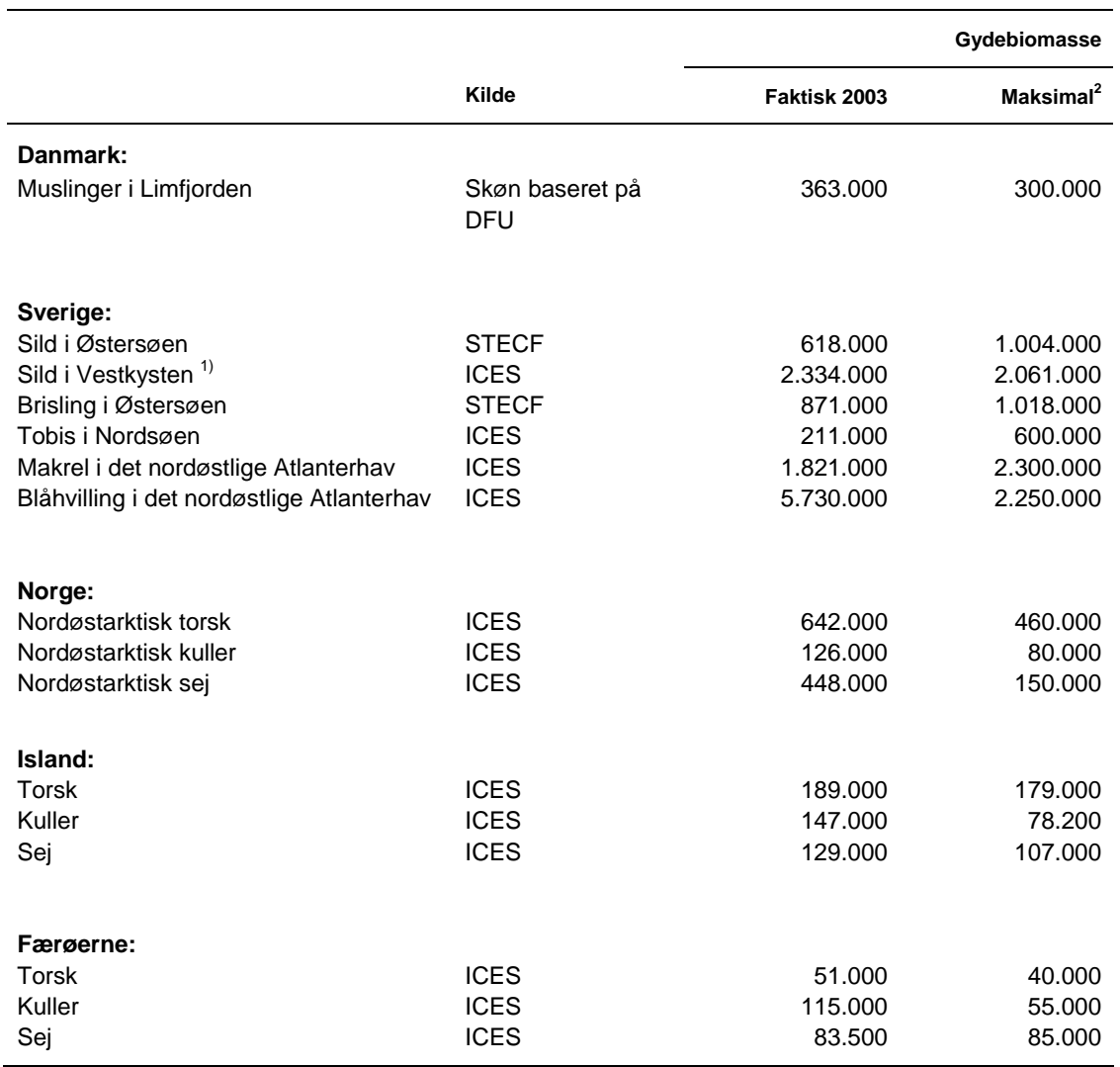

Noter: 1. Disse inkluderer sildebestandene i Nordsøen, Skagerrak og Kattegat.

2. For Island kendes den maksimale biomasse ikke, da forsigtighedsprincippet ikke anvendes, hvorfor den gennemsnitlige biomasse over de sidste ti år er anvendt.

Forudsat at vi er i ligevægt i den nuværende situation (2003), dvs. at fiskeriindsatsen er bæredygtig, vil en gydebiomasse, mindre end den der giver den maksimale fangst, indebærer, at fangsterne kan forøges ved at reducere fiskerindsatsen. Ressourcerenten kan derved forøges. Den maksimale ressourcerente opnås dog ikke nødvendigvis ved den fiskeriindsats, der giver de størst mulige vedvarende fangster, men der hvor forskellen mellem omkostninger og indtægter er størst. Det kan under normale forudsætninger i et fiskeri på en art vises, at være ved en fiskeriindsats der er mindre end den, der giver den maksimale vedvarende fangst.

Såfremt vi ikke er i ligevægt i den nuværende situation vil ressourcerenten være upræcist beregnet. Hvis fiskeriet (fiskeridødeligheden) ikke er bæredygtigt, er der risiko for at rekrutteringen svigter, hvilket kan medføre, at den maksimale ressourcerente er overvurderet. Hvis fiskeriet er bæredygtigt, er denne risiko minimal og ressourcerenten rimeligt præcist beregnet. 


\subsubsection{Resultater}

Ved anvendelse af metode og data beskrevet i afsnit 4.2.1. og 4.2.2 beregnes den maksimale ressourcerente som angivet i tabel 7. Ressourcerenten 2001-2003 er angivet til sammenligning, såvel som den nødvendige flådetilpasning for at opnå den maksimale ressourcerente fremgår.

Tabel 7. Den maksimale ressourcerente og flådetilpasning.

\begin{tabular}{|c|c|c|c|c|c|}
\hline & Island & Norge & Færøerne & Sverige & Danmark \\
\hline \multicolumn{6}{|l|}{ Ressourcerente (mio. DKK): } \\
\hline Nuværende & 765 & -176 & 84 & 12 & 80 \\
\hline Maksimal & 1.533 & 142 & 142 & 210 & 92 \\
\hline Potentiel stigning & 768 & 318 & 58 & 198 & 12 \\
\hline \multicolumn{6}{|l|}{ Ressourcerente (i procent af landingsværdi): } \\
\hline Nuværende & $30 \%$ & $-22 \%$ & $28 \%$ & $3 \%$ & $60 \%$ \\
\hline Maksimal & $60 \%$ & $18 \%$ & $47 \%$ & $53 \%$ & $69 \%$ \\
\hline Potentiel stigning & $30 \%$ & $40 \%$ & $19 \%$ & $50 \%$ & $9 \%$ \\
\hline \multicolumn{6}{|l|}{ Flåde (antal fartøjer): } \\
\hline Nuværende & 76 & 1.145 & 29 & 57 & 63 \\
\hline Maksimal & 27 & 310 & 14 & 15 & 41 \\
\hline Reduktion & -49 & -835 & -15 & -42 & -22 \\
\hline - heraf biologiske effekter (bestandstilpasning) & -46 & -737 & -12 & -35 & -18 \\
\hline - heraf efficienseffekter (300 fiskedage om året) & -3 & -98 & -3 & -7 & -4 \\
\hline
\end{tabular}

Den maksimale ressourcerente er størst i det danske muslingefiskeri (69 \%), og på niveau i Island (60 \%), Sverige (53 \%) og Færøerne (47 \%). Den høje maksimale ressourcerente i den danske case skal ses i sammenhæng med, at omkostningerne ved at fiske muslinger er små og at antallet af fartøjer lille.

Resultaterne indikerer, at det synes realistisk at opnå en ressourcerente på maksimalt 47 \%-60 \% i flerartsfiskerier, når der ses bort fra Norge. Der er således forskel mellem hvor stor ressourcerente, der kan opnås, på trods af at fx fiskeriet i Island og Færøerne foregår på nogenlunde de samme bundfiskearter og derfor i teorien burde være nogenlunde lige store. Forskellen kan skyldes, at de islandske fartøjer er større og derfor muligvis mere effektive. Forskellen kan dog også skyldes, at fangstraterne ved Island traditionelt har været bedre end ved Færøerne.

Den relativt lave maksimale ressourcerente i Norge afspejler strukturelle forhold, der kan henføres til at fiskeriet er sæsonbetonet og at fartøjerne derved ikke kan udnyttes fuld effektivt året rundt. Samtidig har det betydning, at den alternative aflønning af kapital og arbejdskraft er høj, at fangstraterne kan være lavere end andre steder, samt i mindre omfang at regionale prioriteringer medfører højere omkostninger end i de øvrige flådesegmenter. I Norge fiskes på nogenlunde de samme bundfiskearter som i Island og til trods herfor, er den maksimale ressourcerente kun ca. en tredjedel af, hvad den er i Island. Forudsat at de biologiske forhold i Norge er lige så gode som i Island og hvis de små norske fartøjer blev erstattet med fartøjer, der er lige så effektive som de islandske, kan ressourcerenten således tredobles. „Prisen“ for at opretholde fiskeri med 
mindre kystfartøjer i et spredt geografisk område i forhold til at føre en politik, der tilsigter at maksimere ressourcerenten, kan således være op til forskellen mellem den islandske og norske maksimale ressourcerente, dvs. $42 \%$ af landingsværdien.

Det fremgår endvidere af tabellen, at ressourcerenten kan forøges i alle de fem udvalgte fiskerier uden at ændre den nuværende flådestruktur. Den potentielle stigning er størst i Sverige, hvor ressourcerenten kan forøges med, hvad der svarer til 50 \% af landingsværdien. Også i Norge (40 \%) og i Island (30 \%) kan der opnås væsentlige forøgelser i ressourcerenten. I Færøerne (19 \%) og i Danmark (9 \%) er de potentielle forøgelser mindre.

I de fem betragtede fiskerier kan ressourcerenten samlet forøges med 1,4 mia. DKK. Forudsat at der ønskes ført en politik, der har til hensigt at forøge det samfundsmæssige udbytte af fiskeriet, er der således et væsentligt potentiale i alle de udvalgte fiskerier. Selv uden at ændre flådestrukturen er der en potentiel samfundsmæssig gevinst på 1,4 mia. DKK. Såfremt de fem fiskerier havde været repræsentative for hele fiskeriet i de fem lande, ville der have været en potentiel samfundsmæssig gevinst på 6,7 mia. DKK. Denne gevinst ville yderligere kunne forøges yderligere, såfremt der føres en politik, der ikke sætter begrænsninger på størrelsen og derved effektiviteten af fiskefartøjer.

Den maksimale ressourcerente opnås ved at reducere antallet af fartøjer i alle fem fiskerier. I Danmark reduceres med ca. en tredjedel og i Færøerne halveres antallet, hvor det reduceres med 2/3 eller mere i de øvrige fiskerier. I flerartsfiskerierne kommer hovedeffekten fra regenerering af bestandene som følge af, at reduceret fiskeridødelighed nødvendiggør tilstedeværelsen af mindre kapacitet og derved mindre omkostninger. Bedre udnyttelse af fartøjerne (hhv. 300 og 225 dage pr. år) giver kun en mindre effekt.

Nedenstående vurderes om antagelsen om ligevægt initialt er rimelig. Det vurderes den at være i fiskerier hvor fiskeridødelighedsniveauet i dag er mindre end forsigtighedsprincippet tilsiger. Fiskeridødelighedsniveauer er angivet i tabel 8.

Det fremgår, at antagelsen om initial ligevægt er rimelig i Danmark og til dels i Norge, men ikke i Island, Færøerne og Sverige. Dette indebærer at den maksimale ressourcerente i Island, Færøerne og Sverige kan være overvurderet, da der er forøget risiko for svigtende rekruttering, som kan reducere fremtidige fangstmuligheder ${ }^{9}$.

\footnotetext{
${ }^{9}$ Resultaterne kan sammenlignes med beregninger af den maksimale ressourcerente. De undersøgleser der jf. note ${ }^{\text {vi }}$ identificerer den faktiske ressourcerente, beregner også den maksimale ressourcerente. Disse er få men der er, som tilfældet var med den nuværende ressourcerente, foretaget beregninger for Norge og Island. I Norge beregner Steinshamn (2005) den maksimale ressourcerente, defineret som den ressourcerente, der opnås uden andre begrænsninger på fiskeriet end af teknisk og biologisk karakter og med en alternativ forrentning af kapitalen på $7 \%$, til 7,1 mia. NOK. Dette svarer til $68 \%$ af landingsværdien. I Island beregner Gudmundsson et al (2001) den maksimale ressourcerente i det islandske trawlerfiskeri til 50-65 \% af landingsværdien. Resultaterne i dette
} 
Tabel 8. Biologisk rådgivning om fiskeridødelighedsniveauer.

\begin{tabular}{ll}
\hline & Fiskeridødelighedsniveau \\
\hline $\begin{array}{l}\text { Danmark: } \\
\text { Muslinger i Limfjorden }\end{array}$ & \\
Sverige: & Bæredygtigt \\
Sild i Østersøen & \\
Sild i Skagerrak og Kattegat & Risiko for ikke at være bæredygtigt i øst. \\
Brisling i Østersøen & Referencepunkter ikke defineret i vest. \\
Tobis i Nordsøen & Bæredygtigt. \\
Makrel i det nordøstlige Atlanterhav & Ingen rådgivning \\
Blåhvilling i det nordøstlige Atlanterhav & Referencepunkter ikke defineret \\
& Ikke bæredygtig \\
Ikke bæredygtig \\
Norge: & \\
Nordøstarktisk torsk & Højere end intention i forvaltningsplan \\
Nordøstarktisk sej & Bæredygtig \\
Island: & Bæredygtigt \\
Torsk & \\
Kuller & \\
Sej & Fiskeridødelighed for høj \\
Færøerne: & Referencepunkter ikke defineret \\
Torsk & Forøget risiko for ikke at være bæredygtigt \\
Kuller & \\
Sej & \\
\hline Kilde: ICES. & Ikke bæredygtigt (Færø plateau) \\
& Forøget risiko for ikke at være bæredygtigt \\
& \\
\hline &
\end{tabular}

\subsection{Instrumenter til forøgelse af ressourcerenten}

Beregningen af den maksimale ressourcerente baseredes på en række forudsætninger bl.a. vedrørende de biologiske forhold, som indebærer, at den præcise størrelse af den maksimale ressourcerente er usikker.

Der er således et potentiale for at forøge ressourcerenten og derved det samfundsøkonomiske udbytte af fiskebestandene. Såfremt dette potentiale skal realiseres fuldt ud, kræver det, at det langsigtede samfundsøkonomiske udbytte prioriteres eksplicit som den vigtigste fiskeripolitiske målsætning. Såfremt potentialet skal udnyttes delvist, er kravet at målsætningen om samfundsøkonomisk udbytte prioriteres højere.

„Prisen“ vil i begge tilfælde være, at muligheden for at prioritere andre målsætninger i fiskeripolitikken bliver mindre. Dvs. muligheden for at prioritere regionalpolitiske ønsker om et bestemt bosætningsmønster og tilstedeværelse af eksempelvis kystfiskeri med mindre fartøjer i bestemte områder bliver mindre. Også muligheden for at opretholde en høj beskæftigelse i det primære fiskeri begrænses. Prisen vil endvidere være, at samfundet nødvendigvis må opgive noget på kort sigt for at opnå et større samfundsøkonomisk udbytte på lang sigt. Overudnyttede bestande må have tid til at regenerere sig og fiskeriet må begrænses på kort sigt.

studie er således i god overensstemmelse med tidligere undersøgelser på trods af, at der er anvendt forskellige beregningsmetoder. 
Dette indebærer, at fiskerimulighederne for nuværende fiskere bliver mindre, men samtidig at fiskerimulighederne for fremtidige fiskere bliver større.

Instrumentet til at opnå forøget samfundsøkonomisk udbytte er bedre fiskeri-forvaltning. Fiskeriforvaltningen skal nødvendigvis forbedres på følgende områder:

a. Fiskebestande forvaltes bæredygtigt i forhold til både gydebiomasse og fiskeridødelighed.

b. Flådekapacitet, målt som investeret kapital, bringes i overensstemmelse med økonomi og biologi.

c. Der sikres en automatisk strukturtilpasning.

Ad a) Princippet om bæredygtig forvaltning af fiskerierne opnås gennem stadig opretholdelse af en gydebiomasse, der er større end, hvad der giver risiko for rekrutteringssvigt. Også fiskeridødeligheden må opretholdes på et niveau, der ikke giver risiko for fremtidige rekrutteringssvigt. En måde at opnå dette krav på er anvendelse af forsigtighedsprincippet både i den biologiske rådgivning, som det allerede sker i dag, men også ved en konsekvent anvendelse af fiskerireguleringer.

Ad b) Princippet om at bringe flådekapaciteten, målt som investeret kapital, i overensstemmelse med de økonomiske og biologiske muligheder opnås ved at minimere de totale omkostninger ved alle fartøjers fiskeri. Dette sikres ved at have det mindste antal fartøjer, der er i stand til at opfiske den givne mængde, dvs. ved at udnytte kapaciteten bedst muligt.

Ad c) Princippet om at sikre automatisk strukturtilpasning er vigtigt for at give mulighed for fleksibilitet i fiskeflåden. Fx ved flere års rekrutteringssvigt er det vigtigt, fiskeriet hurtigt kan indrette sig efter nye begrænsede fangstmuligheder. Ellers vil fiskeflåden og de totale omkostninger i fiskeriet blive for store. Også ved teknologiske landvindinger, som indebærer, at kapaciteten af det enkelte fartøj og herigennem hele flåden forøges væsentligt, er det af afgørende betydning at flåden samtidig reduceres. Fremkomsten af dobbelttrawlet for nogle år siden er et eksempel på en sådan teknologisk landvinding. Strukturtilpasning kan opnås på en lang række måder, en mulighed er at gøre fiskerirettigheder omsættelighed eller overdragelige.

Såfremt disse tre forhold er opfyldt, er der et godt grundlag for gennem den konkrete fiskeriforvaltning at opnå et væsentligt samfundsøkonomisk udbytte af fiskeressourcerne.

Der kan skelnes mellem fysisk og økonomisk forvaltning. Fysisk forvaltning kan fx være adgangsbegrænsning til fiskeri gennem licenskrav, kvoteregulering, indsatsregulering gennem begrænsning i antallet af havdage, samt redskabsregulering gennem maskestørrelser og mindstemål. Økonomisk forvaltning kan fx være afgift på landinger og afgift på adgang til fiskeri. Markedsbaseret fiskeriforvaltning som individuelt omsæt- 
telige kvoter har elementer af både fysisk og økonomisk karakter, men klassificeres i det følgende som fysisk forvaltning. Begge typer kan i teorien sikre den maksimale ressourcerente (Clark 1990), forudsat at a, b og c opfyldes. I praksis giver økonomisk regulering i form af eksempelvis landingsafgifter, dog en række problemer. Disse inkluderer, at effekten kun vanskeligt kan forudsiges, hvorfor instrumentet bliver upræcist.

Økonomisk forvaltning har i praksis primært været anvendt som et supplement til fysisk forvaltning. Landingsafgifter er så vidt vides ikke anvendt som det bærende fiskeripolitiske instrument nogetsteds i verden. Landingsafgifter har dog flere steder været anvendt ved siden af fysisk forvaltning. Formålet har her været omfordeling af ressourcerenten fra fiskerierhvervet til samfundet og landingsafgifter kan derfor betragtes som et finanspolitisk instrument. Sideeffekten er dog, at fiskeriudøvelsen også påvirkes. Eksempler på nordiske lande, der har anvendt landingsafgifter, er Norge (jf. tabel 3), Grønland (Grønlands Hjemmestyre 2005) og Island.

Alle typer fysisk forvaltning kan i teorien danne grundlag for at forøge ressourcerenten i de fem udvalgte fiskerier, såfremt de anvendes på den rigtige måde og i den rigtige kombination. Det er derfor i ligeså høj grad anvendelsen som tilstedeværelsen af et bestemt system, der er afgørende for om ressourcerenten kan forøges. Opnåelse af den maksimale ressourcerente forudsætter imidlertid, at de tre krav (a, b og c) opfyldes. Dvs. at fiskebestande forvaltes bæredygtigt, at flådekapacitet bringes i overensstemmelse med økonomi og biologi og at der sikres en automatisk strukturtilpasning. Kun bestemte typer fiskeriforvaltning kan således danne grundlag for at opnå den maksimale ressourcerente.

De fem udvalgte fiskerier repræsenter hver sin type forvaltningssystem. I Island forvaltes med individuelt omsættelige kvoter og dette system genererer en ressourcerente (type A) på $30 \%$ af landingsværdien. Potentielt kan denne forøge til $60 \%$. Potentielt vurderes den eksisterende forvaltning at kunne generere den maksimale ressourcerente, men trods det forhold at det individuelt omsættelige kvotesystem blev indført for mere end 20 år siden, er strukturtilpasningen stadig ikke fuldt gennemført. Opnåelsen af den maksimale ressourcerente tager således på trods af tilstedeværelsen af de rette forvaltningsinstrumenter lang tid.

I Norge forvaltes kystfiskeriet ved individuelt ikke omsættelige kvoter. Der genereres en negativ ressourcerente på $22 \%$ af landingsværdien. Denne kan potentielt med den nuværende flådestruktur, dvs. uden at der tillades at mindre fartøjer udskiftes med større, forøges til $18 \%$ af landingsværdien. Den maksimale ressourcerente vurderes ikke, at kunne opnås med den eksisterende individuelt ikke omsættelige kvoteforvaltning. Indenfor rammerne af den eksisterende forvaltning vurderes ressourcerenten dog stadig at kunne forøges, bl.a. ved en forbedret kapacitetsudnyttelse kombineret med en hurtigere strukturtilpasning. Udfordringen i dette fiskeri består bl.a. i det faktum, at fiskeriet hovedsageligt er 
sæsonbaseret. Flåten \& Hermansen (2005) har således foretaget et studie af sæsonudsvingene og det kapløb efter fisk, som i mange tilfælde har været resultatet. Endvidere viste Andreasson og Flaaten (1996), at der er et stort potentiale for at generere ressourcerente ved at begrænse adgangen til fiskeri og fangst, samt ved rigtigt valg af selektionsmønster.

I Færøerne forvaltes fiskeriindsatsen i form af begrænsninger i antallet af havdage. Der genereres en ressourcerente på $28 \%$ af landingsværdien som potentielt kan forøges til $47 \%$. Havdageregulereringen vurderes, som det islandske individuelt omsættelige kvotesystem potentielt, at kunne generere den maksimale ressourcerente. Forudsætningen er, at systemet anvendes på den rigtige måde og indrettes til at tage højde for den teknologiske udvikling. Således skal en teknologisk landvinding, der forøger den samlede fangstkapacitet, som fx introduktionen af dobbelttrawl, automatisk medfører, at det totale antal havdage såvel som flådekapaciteten reduceres tilsvarende. Også den løbende teknologiudvikling skal indarbejdes i den årlige fastsættelse af det totale antal havdage.

I Sverige reguleres stimefiskeriet i dag med rationer, hvor hvert fartøj over en nærmere afgrænset tidsperiode fx 2 uger tildeles en ration. Når denne er opfisket, skal fiskeriet indstilles. Der genereres en ressourcerente på $3 \%$ af landingsværdien i fiskeriet, som potentielt kan forøges til 53 \%. Den måde hvorpå stimefiskssegment har været forvaltet, har således medført overkapacitet og dårlig lønsomhed. Det vurderes, at den maksimale ressourcerente indenfor rammerne af den nuværende forvaltning, ikke kan opnås. Erhvervet har i samarbejde med Fiskeriverket udarbejdet et forslag til forvaltning med individuelt omsættelige kvoter. Systemet indebærer, at hvert fartøj tildeles en andel af den svenske kvote, som kan fiskes, når det er mest lønsomt, uden at der er risiko for, at kvoten opfiskes af andre.

I Danmark forvaltes muslingefiskeriet ved adgangsbegrænsninger i form af licenser. Oveni kommer en række detailbegrænsninger med periodelukninger af områder og forbud mod fiskeri i bestemte perioder. Adgangsbegrænsningen har i en årrække været meget restriktiv og ressourcerenten er således $60 \%$ af landingsværdien. Denne kan potentielt forøges til 69 \%. Udfordringen består fremover i en mere effektiv strukturtilpasning. 


\section{Ressourcerentens fordeling}

Fiskerilovgivningerne i flere af de nordiske lande angiver, at samfundet som helhed ejer fiskebestandene. De angiver imidlertid ikke noget om, hvem i samfundet, der ejer fiskebestandene og derfor heller ikke noget om, hvem der har krav på ressourcerenten. Deltagere i fiskeriaktiviteter, ejere af og ansatte på fiskefartøjer, kan have et legitimt krav på at få en andel. Ejere såfremt der er større risiko i at investere i fiskefartøjer end i andre erhverv. Arbejdskraften i det omfang der er større ulemper forbundet med at arbejde som fisker end i andre erhverv. Såfremt det ikke sikres, at der investeres den nødvendige kapital i fiskeriet samt rekrutteres den nødvendige og bedst mulige arbejdskraft, kan ressourcerenten ikke opretholdes. Kapital og arbejdskraft skal således som minimum opnå den andel af ressourcerenten, der sikrer fiskeri på et niveau, hvor den samlede ressourcerente ikke falder.

Samtidig har det resterende samfund, repræsenteret ved den offentlige sektor, som ejer af fiskebestandene også et legitimt krav på en andel af ressourcerenten. Denne andel opnås gennem skattesystemet $\mathrm{i}$ form af indkomstskat, selskabsskat, i visse lande en mindre ressourceskat og i nogle få lande betaling for fiskeriforvaltning, kontrol og ejerskab af fiskerirettigheder. Disse offentlige indtægter imødegås dog af offentlige udgifter til fiskeriet i form af tilskud og fiskeriforvaltningsomkostninger.

Fiskeriet kan sammenlignes med andre erhverv, hvor produktionen er baseret på naturressourcer. Således er der en skat på olie i Norge, hvor der opkræves $50 \%$ af overskuddet af olieproduktionen oveni den generelle selskabsskat på $28 \%$. Også på vandkraft i Norge eksisterer en ekstra høj kommunal afgift. I Danmark er der forhandlet en aftale på plads om skat på olie og naturgas. Ressourceskat i nordiske fiskerier er imidlertid næsten ukendt og hvor de anvendes, er de meget små. I Norge anvendes således en afgift på 0,2 \% af landingsværdien, såvel som der i Island i 2004 blev indført en afgift på ejerskab af fiskerirettigheder. Denne svarer, når den er fuldt indført i 2008, til ca. 2 \% af landingsværdien.

Der vurderes at være et potentiale for, at den offentlige sektor som ejer af fiskeressourcerne kan opnå en større andel af ressourcerenten. Muligheden begrænses i de tilfælde hvor samfundet tilbage i tiden har tildelt et begrænset antal fiskere eksklusive rettigheder til fiskeri og når disse fiskere har videresolgt de tildelte rettighederne til en ny generation. Den nye generation har ved betaling for fiskerirettigheder allerede betalt ressourcerenten én gang. Og denne betaling kan ikke beskattes med tilbagevirkende kraft. Potentialet for den offentlige sektor ligger derfor primært i, at der indføres beskatning, når ressourcerenten forventes at stige i fremtiden. 


\subsection{Ressourcerentens fordeling 2001-2003}

\subsubsection{Beregningsmetode}

Ressourcerentens fordeling mellem kapital, arbejdskraft og den offentlige sektor kan beregnes særskilt for de tre grupper som:

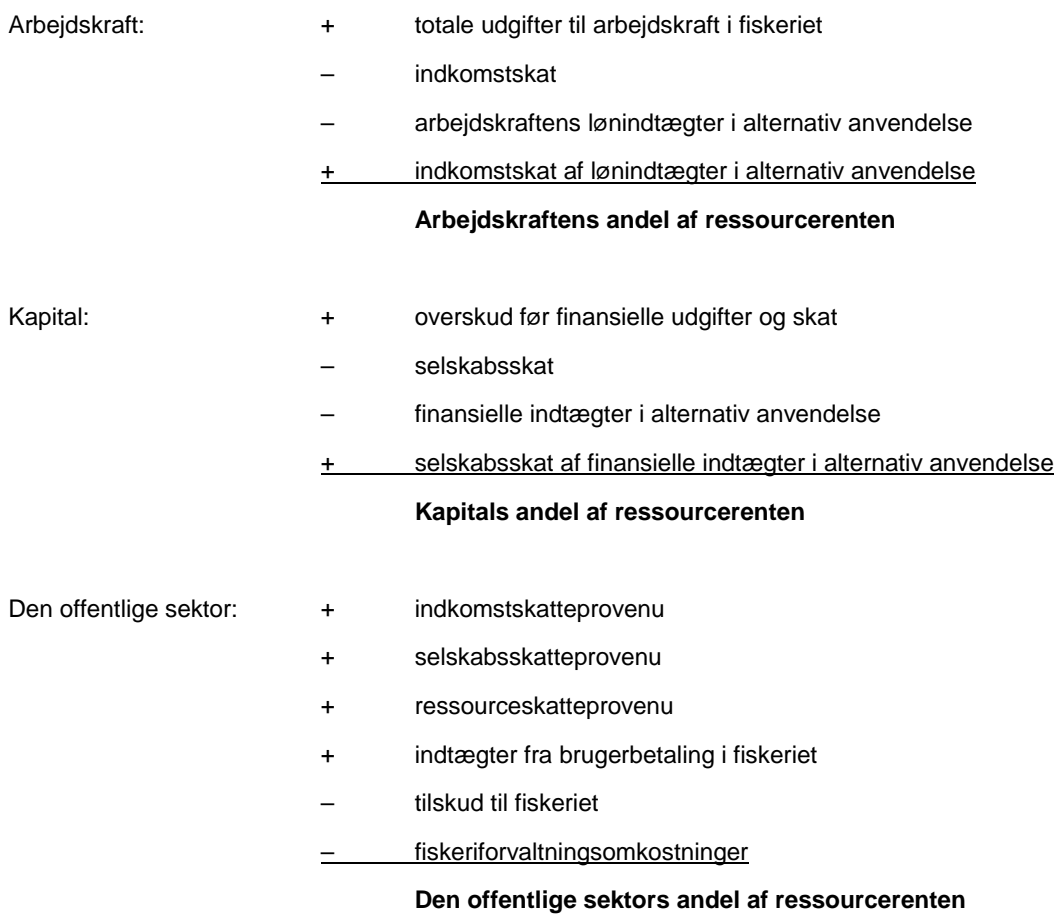

Kapitalens og arbejdskraftens andel af ressourcerenten beregnes uden hensyntagen til om den tilfalder nuværende eller tidligere fiskere. Evt. salg af fiskerirettigheder fra tidligere fiskere til nuværende er ikke inddraget i beregningen. Dette gælder både for salg af licenser særskilt og tilknyttet fiskerfartøjer. Der skelnes således ikke mellem om kapitalens og arbejdskraftens andel af ressourcerenten tilfalder nuværende eller tidligere fiskere.

I beregningen af arbejdskraftens andel af ressourcerenten kendes de totale udgifter til arbejdskraft i fiskeriet og i alternativ anvendelse fra kapitel 4.

Sammenholdes disse med antallet af fuldtidsbeskæftigede i kapitel 3, kendes gennemsnitslønnen i hhv. fiskeriet og i alternativ anvendelse. Indkomstskatten er beregnet på grundlag af disse gennemsnitslønninger gange indkomstskatteprocenten. Indkomstskatteprocenten i fiskeriet identificeres svarende til det gennemsnitlige lønniveau, idet der herigennem tages højde for bundfradrag, fiskerfradrag og skattesystemets progression. Fiskerfradraget antages fuldt udnyttet. Indkomstskatteprocenten i alterna- 
tiv anvendelse beregnes tilsvarende, bortset fra at lønniveauet er anderledes og fiskerfradraget ikke er gældende.

I beregningen af kapitalens andel af ressourcerenten er overskud før finansielle udgifter og skat beregnet efter fradrag af afskrivninger, såvel som selskabsskatten er beregnet som selskabsskatteprocenten gange overskud efter finansielle udgifter. Finansielle indtægter i alternativ anvendelse beregnes som $6 \%$ af den investerede kapital, jf. kapitel 4 og selskabsskat i alternativ anvendelse beregnes som selskabsskatteprocenten gange finansielle indtægter.

I beregningen af den offentlige sektors andel af ressourcerenten anvendes indkomst- og selskabsskatteprovenuet bestemt i beregningen af hhv. arbejdskraftens og kapitalens andel af ressourcerenten. Ressourceskatteprovenuet er i den betragtede periode alene relevant i Norge, hvor den udgør $0,2 \%$ af landingsværdien. Tilskud til fiskeriet, fiskeriforvaltningsomkostninger og indtægter fra brugerbetaling i fiskeriet kendes fra kapitel 4.

Den beregnede fordeling af ressourcerenten baseres således på flere beregnings-forudsætninger. Dette indebærer, at resultaterne er behæftet med betydelig usikkerhed og derfor skal fortolkes med forsigtighed.

\subsubsection{Data}

Regnskabsdata, lønstatistik, data for tilskud til fiskeriet, omkostninger til fiskeriforvaltning og indtægter fra brugerbetaling i fiskeriet er beregnet som angivet i kapitel 4. Skatteprocenter er angivet i tabel 9.

Tabel 9. Skatteprocenter, gennemsnit 2001-2003.

\begin{tabular}{lrrrrr}
\hline & Island & Norge & Færøerne & Sverige & Danmark \\
\hline Selskabsskat & 18 & 28 & 20 & 28 & 38 \\
Indkomstskat i fiskeriet & 35 & 23 & 36 & 48 & 50 \\
Indkomstskat i alternativ anvendelse & 34 & 33 & 38 & 48 & 41 \\
\hline
\end{tabular}

Kilder:Nødvendige data for at udarbejde denne tabel er angivet i rapporten „Focus on the economy of the Nordic fisheries - case study reports from Iceland, Norway, the Faroe Islands, Sweden and Denmark“.

De angivne indkomstskatteprocenter er beregnet under hensyntagen til bundfradrag, fiskerfradrag, skattesystemets progression og arbejdsgiverudgifter. Indkomstskatteprocenterne er beregnet for gennemsnitslønniveauet i hhv. fiskeriet og for arbejdskraft i alternativ anvendelse.

Af tabellen fremgår at selskabsskatten med $18 \%$ er lavest i Island og med 38 \% højest i Danmark. Indkomstskatten er højest i Sverige og lavest i Norge, både i fiskeriet og i alternativ anvendelse. Der er bundfradrag og progression i skattesystemet i alle de nordiske lande, men dette slår alene igennem $\mathrm{i}$ højere indkomstskat $\mathrm{i}$ fiskeriet end $\mathrm{i}$ andre erhverv specielt $\mathrm{i}$ Danmark, men også i Island. I Norge og i Færøerne er indkomstskatteprocenten lavere i fiskeriet end i andre erhverv, hvilket skyldes tilstedeværelsen af fiskerfradrag og i Norge også en lavere aflønning i fiskeriet. I Sverige er indkomstskatteprocenten ens i fiskeriet og i andre erhverv, idet 
lønniveauet i fiskeriet er på niveau med andre erhverv, samt fordi der ikke eksisterer fiskerfradrag.

\subsubsection{Resultater}

Ressourcerentens fordeling som årligt gennemsnit over 2001-2003 er angivet for de fem udvalgte fiskerier i tabel 10. Ressourcerenten er angivet efter fradrag af offentlige nettoudgifter til fiskeriet (type B).

Tabel 10. Fordeling af ressourcerenten (type B), 2001-2003, mio. DKK og pct.

\begin{tabular}{lrrrrr}
\hline & Island & Norge & Færøerne & Sverige & Danmark \\
\hline Nettoaflønning af kapital & 174 & -58 & 17 & 22 & 33 \\
Nettoaflønning af arbejdskraft & 371 & -14 & 43 & -1 & 12 \\
Skatteindtægter & 220 & -103 & 24 & -8 & 35 \\
Andre offentlige nettoudgifter til fiskeriet & $\underline{-49}$ & $\underline{-93}$ & $\underline{-25}$ & $\underline{-92}$ & $\frac{-22}{58}$ \\
Total & 716 & -268 & 59 & -80 & \\
Procentuel fordeling af ressourcerenten1 & & & & & \\
Kapital & 24 & -22 & 28 & 27 & 56 \\
Arbejdskraft & 52 & -5 & 76 & -2 & 20 \\
Den offentlige sektor & $\underline{24}$ & $\underline{-73}$ & $\underline{-4}$ & $\underline{-125}$ & $\underline{24}$ \\
Total & 100 & -100 & 100 & -100 & 100 \\
\hline
\end{tabular}

Noter:1. Minus angiver at sektoren bidrager negativt til ressourcerenten.

Kilder: Nødvendige data for at udarbejde denne tabel er angivet i rapporten „Focus on the economy of the Nordic fisheries - case study reports from Iceland, Norway, the Faroe Islands, Sweden and Denmark“.

Den offentlige sektors andel af ressourcerenten er positiv i Island og Danmark og udgør begge steder $24 \%$. Den offentlige sektors andel er imidlertid negativ i de øvrige tre lande, mest i Sverige (-125\%) og Norge (-73 \%) og mindre i Færøerne (-4 \%). I disse lande er fiskerisektorens bidrag til den offentlige sektor således mindre end den er i andre sektorer, dvs. det offentlige har relativt flere udgifter end indtægter fra fiskeriet set i sammenligning med andre sektorer.

Kapitalens andel af ressourcerenten er med 56 \% størst i Danmark og nogenlunde på niveau i Færøerne, Sverige og Island. Forrentningen efter skat er otte gange større end i andre erhverv i Danmark, 133 \% større i Island, dobbelt så stor i Færøerne og $46 \%$ større i Sverige. I Norge er kapitalens andel negativ. Kapitalaflønningen er således væsentligt større i fiskeriet end i andre erhverv i alle de udvalgte fiskerier bortset fra kystfiskeriet i Norge.

Arbejdskraftens andel af ressourcerenten er med 76 \% størst i Færøerne, men også højere end i andre erhverv i Island og Danmark. Lønnen efter skat er i Færøerne og i Island mere end dobbelt så meget som i andre erhverv (hhv. 117 \% og 111 \% større). I Danmark er aflønningen 72 \% større. Sammenligningen er mellem fiskere, der arbejder to fangstrejser og holder fri en og fuldtidsansatte arbejdere på land. I Norge og Sverige er lønniveauet i de udvalgte fiskerier nogenlunde på niveau med andre erhverv. I Norge og Danmark er kapitalejerne (fartøjsejerne) imidlertid i de fleste tilfælde aktive også som arbejdskraft. Bemandingen udgøres af ejerne og højst en person yderligere. Dette indebærer, at kapitalens og 
arbejdskraftens andel af ressourcerenten skal betragtes samlet. Den samlede andel af ressourcerenten, der går til kapital og arbejdskraft, udgør i det danske muslingefiskeri $76 \%$, hvor det i Norge er negativt med $27 \%$.

Fordelingen af ressourcerenten i det færøske partrawlersegment er beregnet på grundlag af offentlige nettoudgifter i færøsk farvand, hvilket på grund af omfattende færøsk fjernfiskeri i andre flådesegmenter indebærer, at ressourcerenten er undervurderet, såvel som kapitalens og arbejdskraftens andel heraf er overvurderet. Dette skyldes, at det er antaget, at der alene haves omkostninger til fx fiskeriforvaltning i nære farvande. Antages alternativt at omkostninger til fiskeriforvaltning mv. er lige store, uanset om fiskeriet foregår i færøske eller fjernere farvande, bliver ressourcerenten 68 mio. DKK, arbejdskraftens andel $63 \%$, kapitalens $25 \%$ og den offentlige sektors $13 \%$. Arbejdskraften i Færøerne bevarer således, uanset beregningsmetode, den største andel af ressourcerenten i alle de fem case studier, men den offentlige sektor får en større og nu positiv andel. Ved denne beregningsmetode minder resultaterne om Island, bortset fra at den færøske arbejdskraft stadig er bedre aflønnet end den islandske og at det sker på bekostning af den færøske landskasse.

Ressourcerentens fordeling mellem aktive fiskere og tidligere fiskere, som evt. har fået fiskerirettigheder foræret og har solgt dem, er ikke inddraget i beregningerne. Data har ikke været tilgængelige, hvorfor arbejdskraft og kapital inkluderer både aktive fiskere og tidligere fiskere tilbage til dem, der som de første fik tildelt eksklusive fiskerirettigheder gratis. Såfremt ressourcerenten har været konstant over tid og de aktive fiskere har betalt „fuld“ pris til de tidligere fiskere, tilfalder hele arbejdskraftens og kapitalens andel af ressourcerenten de tidligere fiskere. Såfremt fiskerirettigheder i dag uddeles til de nuværende fiskere, tilfalder hele ressourcerenten dem.

Trods manglende mulighed for at foretage konkret beregninger vurderes det, at både tidligere og nuværende fiskere har andel i ressourcerenten i de fem udvalgte fiskerier. Dette skyldes, at fiskeriforvaltningen over de sidste 2-3 årtier gradvist er forbedret. Først med tekniske bevaringsforanstaltninger som maskestørrelser og mindstemål, derefter med begrænsninger i adgangen til udøvelse af fiskeri (licenspligt), efterfulgt af totalkvoter, tildeling af fangstmuligheder herunder individuelt omsættelige rettigheder, indsats og kvoter. Samtidig har priserne på fisk generelt været opadgående.

\subsection{Instrumenter til omfordeling af ressourcerenten}

I afsnit 5.1 blev fordelingen af ressourcerenten mellem arbejdskraft, kapital og den offentlige sektor identificeret. Denne fordeling er resultatet af tilstedeværelsen af det generelle skattesystem, samt af en række offentlige udgifter til fiskeriet. I nærværende afsnit ses på hvilke instrumenter, 
der kan anvendes i en omfordeling af ressourcerenten fra kapital og arbejdskraft til den offentlige sektor. Det vurderes ikke om omfordelingen er ønskelig. Alene instrumenter der er specifikke for fiskerisektoren gennemgås, da det ikke synes realistisk, at eksempelvis det generelle skattesystem kan indrettes med udgangspunkt i fiskerisektoren.

Teoretisk kan både fysisk og økonomisk forvaltning sikre den maksimale ressourcerente men forskellen er, at ressourcerenten under økonomisk forvaltning tilfalder den offentlige sektor, hvor den under fysisk forvaltning, herunder ved markedsbaseret fiskeriforvaltning som individuelt omsættelige kvoter, tilfalder fiskerne (Clark 1990). Den offentlige sektor får dog også gennem det generelle skattesystem andel i ressourcerenten under fysisk forvaltning. En omfordeling fra fiskerne til den offentlige sektor, der ligger ud over den fordeling, det generelle skattesystem indebærer, forudsætter derfor tilstedeværelsen af både fysisk og økonomisk forvaltning. Økonomiske forvaltningsinstrumenter gennemgås derfor i nærværende afsnit som et finanspolitisk omfordelingsinstrument der, supplerer den fysiske fiskeriforvaltning. Samtidig har økonomisk forvaltning dog indirekte effekt på fiskeriforvaltning.

Teoretisk er det at foretrække at introducere omfordeling af ressourcerente samtidig med forbedret fiskeriforvaltning, idet første generations rettighedshavere ikke derved får foræret en skattefri andel af ressourcerenten. I praksis forholder det sig imidlertid anderledes, idet det kun skønnes muligt at omfordele når ressourcerenten gennem forbedret fiskeriforvaltning er blevet synlig. Samtidig er der i næsten alle fiskerier tildelt eksklusive rettigheder til fiskeri, hvor det allerede er for sent at introducere økonomisk forvaltning samtidig med tildeling af rettigheder. Endvidere kan fartøjsejere, der har købt fiskerirettigheder de senere år, få økonomiske vanskeligheder, da de allerede har betalt for ressourceudnyttelsen til tidligere ejere. I de fleste fiskerier er muligheden således at varsle omfordeling fra fiskeriet til den offentlige sektor nogle år i forvejen, således at markedet for fiskerirettigheder kan indrette sig herefter. Kan omfordelingen følges op af sideløbende forbedringer i fiskeriforvaltningen, som forøger ressourcerenten på længere sigt, kan det lette omfordelingens byrder for fiskeriet.

Grønlands Hjemmestyre (2005) angiver at

„et afgiftssystem, der baserer sig på opgørelse af ressourcerenten og derefter afgiftsbelægger denne med den helt rigtige sats er en illusion og administrativ umulig“.

Dette forhold understreges af de usikkerheder, hvormed både størrelsen og fordelingen af ressourcerenten er bestemt i nærværende rapport. Det er imidlertid ikke en illusion, at der eksisterer ressourcerente af en væsentlig størrelse i flere af de fem udvalgte fiskerier, såvel som det ikke er en illusion, at den offentlige sektor på trods af ejerskab af fiskebestandene kun får en beskeden andel heraf og i flere tilfælde direkte har større udgifter 
til fiskeriet end indtægter. Konsekvensen er, at omfordeling af ressourcerenten nødvendigvis skal baseres på et instrument, der er

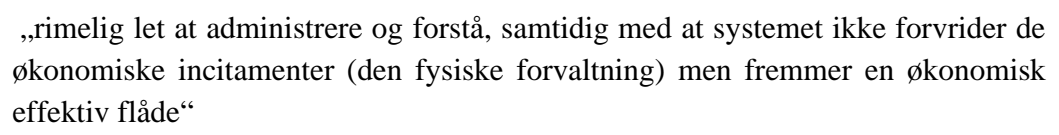

(Grønlands Hjemmestyre 2005).

Instrumenter, der kan anvendes til omfordeling af ressourcerente, kan opdeles i brugerbetaling og afgifter. Brugerbetaling inkluderer salg af fiskerirettigheder på auktion, opkrævning af fiskeriforvaltningsomkostninger og reduktion i favorable ordninger til fiskeriet, herunder tilskud og fiskerfradrag. Fordelen ved disse tiltag er, at de ikke nødvendigvis opfattes som en skat, da der er tale om reelle ydelser, der behandler fiskerierhvervet på lige fod med andre erhverv. Samtidig kan den offentlige sektors nettoudgifter reduceres væsentligt. Specielt ved at opkræve omkostninger til fiskeriforvaltning, herunder for kontrol og biologiske undersøgelser, samt ved at sælge fiskerirettigheder på auktion. Salg af fiskerirettigheder på auktion vil dog kun være fordelagtigt for samfundet, såfremt salget foregår på et frit marked med tilstrækkeligt mange købere. Dette vil ikke nødvendigvis være tilfældet $\mathrm{i}$ alle de fem udvalgte fiskerier.

Beskatningsinstrumenter inkluderer afgifter på landinger, på ejerskab af fiskerirettigheder og på salg af fiskerirettigheder. Fordelen ved afgifter er, at de er forholdsvis lette at administrere, uanset om de beregnes på grundlag af mængder, værdier eller priser. Afgifter beregnet på grundlag af værdier og priser er dog mere fordelagtige end mængdeafgifter, idet mængdeafgifter ikke automatisk har sammenhæng med flådesegmenternes økonomi. Afgifter beregnet på grundlag af salg af fiskerirettigheder har endvidere den fordel, at store og synlige beløb i forbindelse med salg af fiskefartøjer inkl. fiskerirettigheder beskattes. Således bliver kapitalens andel af ressourcerenten meget synlig, når et fartøj til eksempelvis en reel værdi på 10 mio. DKK sælges til 50 mio. DKK som følge af, at rettighederne følger fartøjet. Ulempen med afgiftsordninger er, at forvridningseffekter kan påvirke fiskeriaktiviteterne på utilsigtede og uhensigtsmæssige måder.

I de nordiske lande er erfaringerne med opkrævning af ressourcerente til den offentlige sektor beskedne, ud over de relativt små afgifter i Norge og Island. Dog har der i Grønland eksisteret en afgift på landing af rejer siden 1980'erne (Grønlands Hjemmestyre 2005). Størrelsen af afgiften stiger progressivt med prisen på rejer og minimumsstørrelsen har siden starten af 1990'erne været fastsat på et så højt niveau, at provenuet ikke har oversteget $1 \%$ af landingsværdien.

I lande udenfor Norden kan nævnes erfaringer med omfordeling af ressourcerente til den offentlige sektor i Chile og Rusland, som begge har solgt fiskerirettigheder på auktion. I Chile reduceres alle kvoter med 10 \% om året, som derefter sælges på auktion til højestbydende (Arnason 
2002). I Rusland har kvoter til fiskeriet i Stillehavet også været solgt på auktion (Anferova, Vetemaa og Hannesson 2004). Erfaringerne er imidlertid ikke entydigt positive i de to lande og Rusland anvender ikke systemet mere. Problemerne har bl.a. været, at det begrænsede antal firmaer i Chile har samarbejdet om at holde priserne lave og at de russiske fiskere har købt små kvoter, samtidig med at manglende kontrol har ført til overfiskeri (Grønlands Hjemmestyre 2005).

\subsection{Konsekvensvurdering af omfordeling}

I afsnit 5.2 blev gennemgået en række instrumenter, der kan anvendes til omfordeling af ressourcerenten fra fiskerne til den offentlige sektor. I nærværende afsnit vurderes konsekvenserne. Byrdefordelingen mellem kapital og arbejdskraft, såvel som potentialet ved at forøge de offentlige nettoindtægter ved anvendelse af de forskellige økonomiske forvaltningsinstrumenter, identificeres. Der forudsættes i beregningerne, at strukturen forbliver uændret, såvel som der ses bort fra evt. forvridningseffekter.

Byrdefordelingen af at forøge de offentlige nettoindtægter er angivet i tabel 11 for alle andre initiativer end at afskaffe fiskerfradraget. Byrden ved at afskaffe fiskerfradraget vil alene være fiskernes.

Tabel 11. Byrdefordeling ved omfordeling, pct. af forøgede offentlige nettoindtægter.

\begin{tabular}{lccrrr}
\hline & Island & Norge & Færøerne & Sverige & Danmark \\
\hline Kapital & $45 \%$ & $20 \%$ & $36 \%$ & $71 \%$ & $76 \%$ \\
Arbejdskraft & $55 \%$ & $80 \%$ & $64 \%$ & $29 \%$ & $24 \%$ \\
\hline
\end{tabular}

Kilder: Nødvendige data for at udarbejde denne tabel er angivet i rapporten „Focus on the economy of the Nordic fisheries - case study reports from Iceland, Norway, the Faroe Islands, Sweden and Denmark“.

Byrdefordelingen angiver om, det er kapitalen eller arbejdskraften der på kort sigt bærer byrden ved, at den offentlige sektor forøger nettoindtægterne. Byrdefordelingen afhænger af aftaler mellem kapitalejere og arbejdskraft. I de fleste nordiske fiskerier opnår arbejdskraften, såvel som hver enkelt medarbejder, en fast andel af indtjeningen. Indtjeningen angiver, hvad der er tilbage af fangstværdien efter fradrag af bl.a. brændstof og fartøjsomkostninger. Kapitalaflønningen er så, hvad der er tilbage derefter. Byrdefordelingen afhænger også af indkomst- og selskabsskatteniveauet. Byrdefordelingen på længere sigt afhænger af en lang række forhold, bl.a. genforhandling af lønaftaler og det forhold, at hvis byrden er for stor kan arbejdskraften søge ind i andre erhverv, såvel som kapitalen kan investeres udenfor fiskeriet.

Det fremgår af tabellen at i Norge, Færøerne og Island bærer arbejdskraften størstedelen af byrden, hvor det er kapitalen i Danmark og Sverige. Omfordeling af ressourcerenten til den offentlige sektor vil således primært blive betalt af arbejdskraften i Færøerne og Island, hvor den primært vil blive betalt af kapitalen i Sverige. I Norge og Danmark er kapi- 
talejerne typisk også arbejdskraft og byrdefordelingen er mindre vigtig. Forskellene skyldes bl.a. at der ikke eksisterer fiskerfradrag i Sverige og at ressourcerenten og kapitalaflønningen i Danmark er ekstraordinær høj.

Potentialet $\mathrm{i}$ at forøge de offentlige nettoindtægter ved anvendelse af forskellige typer brugerbetaling og afgifter er meget forskelligt. Ved salg af fiskerirettigheder på auktion kan hele ressourcerenten i teorien opkræves til den offentlige sektor, dog forudsat at auktionssystemet fungerer og prisdannelsen sker under fuldkommen konkurrence. Dette er dog ikke altid tilfældet, da adgang til fiskeri i mange tilfælde er begrænset. Konsekvensen er, at der i mange fiskerier kan være en lille køberskare, som ikke nødvendigvis er i konkurrence. Potentialet i at forøge de offentlige nettoindtægter ved anvendelse af andre typer brugerbetaling, samt ved anvendelse af afgifter er angivet i tabel 12 under antagelse af uændret struktur og aktivitet i fiskeriet.

Tabel 12. Forøgede offentlige nettoindtægter ved omfordeling af ressourcerenten, mio. DKK.

\begin{tabular}{|c|c|c|c|c|c|}
\hline & Island & Norge & Færøerne $^{2}$ & Sverige & Danmark \\
\hline \multicolumn{6}{|l|}{ Brugerbetaling: } \\
\hline Afskaffelse af tilskud & 0 & 9 & 8 & 26 & 8 \\
\hline $\begin{array}{l}\text { Opkrævelse af fiskeriforvalt- } \\
\text { nings_omkostninger }\end{array}$ & ${ }^{3} 49$ & 84 & 25 & 66 & 14 \\
\hline Afskaffelse af fiskerfradraget & 10 & 39 & 14 & 0 & 2 \\
\hline \multicolumn{6}{|l|}{ Landingsafgifter: } \\
\hline $\begin{array}{l}\text { Introduktion af afgift på niveau med } \\
\text { Islands (2008) }\end{array}$ & 56 & 16 & 6 & 8 & 3 \\
\hline Introduktion af afgift på 5 \% & 139 & 40 & 15 & 19 & 8 \\
\hline Introduktion af afgift på $10 \%$ & 278 & 79 & 30 & 39 & 16 \\
\hline $\begin{array}{l}\text { Introduktion af afgift hvor ingen } \\
\text { stilles dårligere }^{1}\end{array}$ & 530 & & 65 & . & 71 \\
\hline
\end{tabular}

Noter:

${ }^{1}$ Afgiften sættes til det laveste niveau hvor hverken arbejdskraft eller kapital aflønnes dårligere end $\mathrm{i}$ andre erhverv. Aflønningen er allerede i dag dårligere end $\mathrm{i}$ andre erhverv i Sverige og Norge.

${ }^{2}$ Beregningen er baseret på at tilskud og fiskeriforvaltningsomkostninger er fordelt mellem flådesegmenterne med udgangspunkt i fiskeriet i færøske farvande.

${ }^{3}$ Denne besparelse omfatter alene den del af fiskeriforvaltningsomkostningerne der ikke allerede opkræves.

De forøgede offentlige nettoindtægter ved brugerbetaling er størst ved opkrævning af fiskeriforvaltningsomkostningerne, men afskaffelse af tilskud og fiskerfradrag er også i visse fiskerier af betydning. Introduktion af en landingsafgift på niveau med den i Island, når den er fuldt indført i 2008, har i sammenligning med brugerbetaling en forholdsvis beskeden effekt på de offentlige nettoindtægter. Forøges landingsafgiften, forøges de offentlige nettoindtægter tilsvarende men så må det også forventes, at det får tilsvarende større konsekvenser for fiskeriaktiviteterne. Fartøjernes rentabilitet påvirkes negativt.

Introduceres hypotetisk den højeste landingsafgift, hvor hverken arbejdskraft eller kapital stilles dårligere end i andre erhverv, opnås de i tabellen angivne afgiftsprovenuer. Disse svarer til landingsafgifter på 19 \% i Island, 22 \% i Færøerne og 45 \% i Danmark. Beregningen er ikke 
foretaget for Norge og Sverige da aflønningen her er dårligere end i andre erhverv. Indregnes et ulempetillæg på fx $50 \%$ af nettolønnen med henblik på at sikre tilstedeværelsen af kvalificeret arbejdskraft og en risikopræmie på fx $10 \%$ af nettoforrentningen for at sikre tilstrækkelig risikovillig kapital, vil de beregnede landingsafgifter falde. Det understreger, at beregningen er hypotetisk, idet introduktion af meget høje landingsafgifter vil medføre forvridningseffekter og ændret struktur i fiskeriet. Men beregningen illustrerer, at der i de tre lande er luft til omfordeling af ressourcerenten fra kapital og arbejdskraft til den offentlige sektor

De forøgede offentlige nettoindtægter ved at indføre afgifter på salg af fiskerirettigheder er ikke identificeret, da datamaterialet er begrænset. I Island har data for salg af individuelle årskvoter dog været tilgængelige. Der blev i kvoteåret 2004-2005 solgt 18.500 tons torsk til en samlet værdi af 167 mio. DKK. Introduceredes en salgsafgift på fx 33 \% ville der kunne opnås et afgiftsprovenu på 56 mio. DKK. Dette svarer til afgiftsprovenuet fra den eksisterende afgift på ejerskab af fiskerirettigheder, når den i 2008 er fuldt indført. Denne afgift vil imidlertid begrænse fartøjernes fleksibilitet, da det vil blive dyrere at sælge årskvoter. Der har ikke været data tilgængelige for permanente salg. 


\section{Referencer}

Andreasson, S. and Flaaten, O. (1996), Bioeconomic and biological effekcts of size selective harvesting of North-East Artic cod, Theme Session on Management faced with Multiple Objectives. C.M. 1996/P:4. ICES.

Anferova, E., M. Vetemaa og R. Hannesson (2004), Fish quota actions in the Russian far east: a failed experiment, paper presented at the Conference at the International Institute of Fisheries Economics and Trade in Tokyo.

Arnason, R. (2002), A review of international experiences with ITQs, An annex to future options for UK fish quota management, Hatcher, A., S. Pascoe, R. Banks, and R. Arnason (ed.).

Clark, C. W. (1990), Mathematical Bioeconomics - the optimal management of renewable resources, second edition, John Wiley \& Sons, Inc.

Copes, P. (1972), Factor Rents, Sole Ownership and the Optimum Level of Fisheries Exploitation, The Manchester School of Social and Economic Studies, 40, 145-63.

Frost, H. (2004), Naturressourcer som fisk og olie i et frit marked. Det går ikke, Samfundsøkonomen, 2, 30-37.

Flåten, O and Hermansen, Ø. (2005). Kappfiske - problem eller løsning? Working Paper Series in Economics and Management No. 01/05.

Færøernes Landsbank (2006), personlig kommunikation med Kari Petersen.

Gordon, H. Scott (1954): The economic theory of a common property resource: the fishery. Journal of Political Economy 62: 124-142.

Grønlands Hjemmestyre (2005), Omscttelige kvoter og andre metoder til regulering af rejefiskeriet, rapport fra det uvildige udvalg, nedsat af Grønlands Hjemmestyre, november.

Gudmundsson, E., A. B. Bergsson, T. Sigurdsson and H. T. Valtysson (2001), Development of catch, fishing effort and fishing fleet capacity in the Icelandic trawler fishery, report to the EU funded project Modelling fishermen behaviour under new regulatory regimes, QLRS2001-01535.

Nordic Council of Ministers (2000), The Status of Fisheries and Related Environment of Northern Seas, a report prepared for the Nordic Council of ministers by ICES, Nord Fisheries 2000:10.

Organisation of Economic cooperation and Development (2000) Transition to responsible fisheries: Economic and policy implications, Paris.

Organisation of Economic cooperation and Development (2003), Review of Fisheries in OECD Countries 1998-1999, Paris.

Organisation of Economic cooperation and Development (2004), The costs of managing fisheries, Paris.

Organisation of Economic cooperation and Development (2005), Review of fisheries in 2001-2003, Paris.

SEC (2004), The Potential Economic Impact on Selected Fishing Fleet Segments of TACs Proposed by ACFM, Report of the Scientific, Technical and Economic Committee for Fisheries, Subgroup on Economic Assessment, Brussels 27-29 October 2004, Commission Staff Working Paper, Brussels, 23.12.2004.

Rasmussen og Weihe (2005), Regnskabsanalyse af fiskeflåden 2000-2004, Revisionsfirmaet Rasmussen og Weihe.

Steinshamn, S.I. (2005), Ressursrenten $i$ norske fiskerier, SNF rapport nr. 06/05.

The International Council for Exploration of the Sea (2003), Report from the Advisory Committee of Fisheries Management, available at http://www.ices.dk/indexfla.asp.

Warming, J. (1911), Om grundrente af fiskegrunde, Nationaløkonomisk Tidsskrift, 49, 499-505.

Warming J. (1931), Aalegaardsretten, Nationaløkonomisk Tidsskrift, 69, 151-162. 


\section{English Summary}

\section{Focus on the Economy of the Nordic Fisheries}

Biological concerns have traditionally formed the core of fisheries management in the Nordic countries. The fisheries management is based on the principle that fish stocks will be exploited on a sustainable level. Management has to some extent targetted economic returns in the fisheries sector and Society. The implication is thus that a considerable potential for increasing the economic returns of the Nordic fisheries sectors and their societies through a reduction in the invested capital in fishing vessels, exists.

The purpose of this report is to focus on fisheries management tools used in obtaining the largest possible economic return of the fisheries, including who obtains the economic return, and how it is allocated between the fishing industry and the public sector.

The report analyses the following cases:

1. Individual transferable quota system in the Icelandic trawling fishery;

2. Individual non-transferable quota system in the Norwegian coastal fishery;

3. Days at sea limitations in The Faroe Islands pair-trawling fishery;

4. Ration-regulated Swedish pelagic fishery; and

5. Licence-regulated Danish mussel fishery.

The economic return of Society is measured by the resource rent, which shows "the return which is left to the remuneration of capital and labour above the level in other businesses". The resource rent in 2001-2003 forms from $60 \%$ of the landing value in the Danish mussel fishery, to minus $22 \%$ in the Norwegian coastal fishery. In the Icelandic trawler fishery and the Faroese pair-trawling fishery, the resource rent is $30 \%$ and $28 \%$ respectively, while in the Swedish pelagic fishery it is $3 \%$.

The maximum resource rent is calculated with the help of a bioeconomic model subject to a number of assumptions on biology, economy, fleet structure and fishing pattern. According to these assumptions, the maximum resource rent in the Danish mussel fishery is calculated at $69 \%$ of the landing value, at a little less in the Icelandic case (60\%), at $53 \%$ in the Swedish case and at $47 \%$ in the Faroese case. The maximum resource rent is lowest in the Norwegian coastal fishery, at $18 \%$.

The purpose of obtaining the maximum resource rent is, however, not necessarily in accordance with other purposes of the fisheries policy, including those on regional policy, employment, settlement and require- 
ments of a particular fleet structure. Therefore, the purpose of obtaining the largest possible resource rent must be prioritised along with the other purposes of the fisheries policy. The maximum resource rent may be obtained through improved fisheries management with a focus on biology, economy and automatic structural adjustment.

The allocation of the resource rent between capital, labour and the public sector, after the deduction of public net expenses to the fisheries, including fisheries management costs, shows that the public sector obtains a positive share of the resource rent in the Icelandic and Danish cases. In the Norwegian, Faroese and Swedish cases, the public sectors share of the resource rent is negative. Thus, the fishing laws in most Nordic countries state that the public owns the fish stocks, while simultaneously the net return to the public from the fisheries is negative in three of the countries.

The resource rent after deduction of public net expenses to the fisheries is negative in Norway and Sweden, but the allocation shows that the remuneration of labour in both countries is approximately at the same level as in other businesses. The remuneration of capital is lower than in other businesses in Norway, but greater in Sweden. The positive resource rent in Iceland and in the Faroe Islands allocates more to labour than to capital. In Denmark, the allocation of resource rent to labour and capital is affected by the fact that the vessels are small and further that the owners are often labourers as well as capital owners.

The resource rent can be reallocated from capital and labour to Society. This can be done in several ways, e.g. by introducing a tax on landings, by phasing out subsidies to the fisheries sector and by collecting fees on fisheries management costs. The possibility is, however, limited in situations where the current generation of fishermen have purchased and paid for their fishing rights from previous generations of fishermen.

It should be pointed out that the results in this report are based on a number of calculation assumptions, both in relation to the size and allocation of the resource rent, as well as in relation to the maximum resource rent. Therefore, the results are encumbered with uncertainty, implying that they should be interpreted cautiously. 


\section{Bilag: Beregning af den maksimale ressourcerente}

Dette bilag er en teknisk gennemgang af en simpel bio-økonomisk model, som anvendes til at beregne den maksimale ressourcerente i afsnit 4.2. Modellen tager udgangspunkt i EIAA-modellen (som står for Economic interpretation of ACFM advice), og som anvendes i den videnskabelige rådgivning af EU's Generaldirektorat for Fisk (SEC 2004). Der antages ligevægt initialt, hvilket bl.a. betyder, at den initiale fiskeridødelighed ikke giver forøget risiko for reduktion i rekrutteringen til fiskerierne. Det antages endvidere, at flådesegmenterne fisker en fast andel af bestandene, samt at andre indtægter end landinger af kvoterede arter er konstant.

Modellen er statisk-komparativ og der sammenlignes to situationer, den nuværende og en ny. Den nye situation findes som den, der giver den maksimale ressourcerente, dvs. ved det maksimale økonomiske udbytte (maximum economic yield - MEY). Den maksimale ressourcerente bestemmes i en optimering, hvor optimeringen gennemføres ved eksperimenter.

Ressourcerenten defineres i forhold til aflønning af produktionsfaktorer i andre erhverv, hvorfor omkostninger til kapital og arbejdskraft er i alternativ anvendelse. Dette indebærer, at det indirekte antages, at det altid er muligt for fiskerne at finde et andet arbejde, dvs. at der er fuld beskæftigelse.

Totalomsætningen er givet ved:

$$
T=p L+O T
$$

hvor $T=$ totalomsætningen, $p=$ pris, $L=$ landinger, $O T=$ indkomst fra ikke kvoterede arter. Priser beregnes i løbende prisniveau og antages konstante. Produktionsfunktionen er givet ved:

$$
L=a X e^{-(b X)}
$$

hvor $X=$ biomasse, og $a$ og $b$ parametre i produktionsfunktionen. Ændringer i fiskeriindsatsen, målt som antallet af havdage $(\mathrm{H})$, antages at afhænge af ændringer i biomassen som angivet i (3):

$$
\frac{X_{1}}{X_{o}}=\beta\left(\frac{H_{1}}{H_{o}}\right)^{-z}
$$


hvor $X_{o}=$ den nuværende biomasse og $X_{1}$ en ny biomasse. Det antages at $\beta=z=1$ for at simplificere modellen. Der antages initialt at være biologisk ligevægt og at vi befinder os på produktionsfunktionen. Produktionsfunktionen kalibreres ved at antage, at det betragtede flådesegment fisker en fast andel af bestandene ud i al fremtid. Kalibreringen foretages på grundlag af viden om størrelsen af $X_{o}$ og $X_{1}$, samt den faktiske fangst, som vist i figur 2 .

Da beregningen foretages for det lange sigt er alle omkostninger variable og omkostningsfunktionen er givet ved (4) under antagelse af stigende faktorpriser.

$$
C_{1}=A\left(V C_{o}+F C_{o}\right), \quad A=\alpha\left(\frac{H_{1}}{H_{o}}\right)^{(1+v)}
$$

hvor $V C$ angiver de omkostninger der altid er variable på både kort og lang sigt. FC i nærværende langsigtede model angiver de omkostninger, der på kort sigt er faste, dvs. de omkostninger, der knytter sig til det enkelte fartøj uanset fartøjets aktivitet. Disse inkluderer kapitalomkostninger, afskrivninger og fartøjsomkostninger. $A$ er en skaleringsfaktor for omkostningerne, der beskriver hvor meget de ændrer sig, når vi går fra den nuværende til en ny situation, $\alpha$ er for at simplificere, sat til $1 . v$ er en parameter for forskellen i fiskernes effektivitet. Når $v>0$ er nogle fiskere dygtigere end andre, hvilket medfører et økonomisk overskud (den infra-marginale rente jf. Copes 1972). I nærværende beregning antages at $v=0,33$, baseret på data envelopment analyses (DEA) af forskelle i fiskeres effektivitet. Det antages at omkostningen pr. havdag er konstant. De fartøjsspecifikke omkostninger, der er uafhængige af hvor meget de enkelte fartøjer fisker (dvs. FC), korrigeres endvidere for kapacitetsudnyttelsen, jf. (5).

$$
F C_{1}=F C_{o}\left(\frac{D S_{o}}{D S_{1}}\right)
$$

hvor $D S_{o}$ er antallet af havdage pr. fartøj pr. år i den nuværende situation og $D S_{1}$ er antallet af havdage pr. fartøjer pr. år i en ny situation, som er sat til maksimalt 300/225

Ressourcerenten beregnes som nettooverskud, dog er omkostninger til kapital og arbejdskraft for alternativ anvendelse, da ressourcerenten er defineret som overskudsrenten i forhold til andre erhverv. Ressourcerenten er inkl. den infra-marginale rente, da nogle fiskere er dygtigere end andre og omkostningsfunktionen derved konveks. Ressourcerenten i den nuværende og i en ny situation er givet ved hhv. (6) og (7). 


$$
\begin{aligned}
& R_{o}=\left(L_{o} p+O T\right)-V C_{o}-F C_{o} \\
& R_{1}=\left(L_{1} p+O T\right)-A\left(V C_{o}+F C_{o} \frac{D S_{o}}{D S_{1}}\right)
\end{aligned}
$$

hvor $R_{o}=$ den nuværende ressourcerente og $R_{1}=$ en ny ressourcerente. I modellen eksperimenteres med fiskeriindsatser på lang sigt (antal havdage) og den fiskeriindsats der giver den maksimale ressourcerente identificeres som i (8), givet en antaget maksimal kapacitetsudnyttelse på 300/225 havdage pr. fartøj pr. år.

$$
\underset{H}{\operatorname{Max}\left(R_{1}\right)} \text {, givet } D S_{1}=300
$$

Maksimeringen i (8) er illustreret grafisk i figur 1.

Figur 1. Nuværende og maksimal ressourcerente.

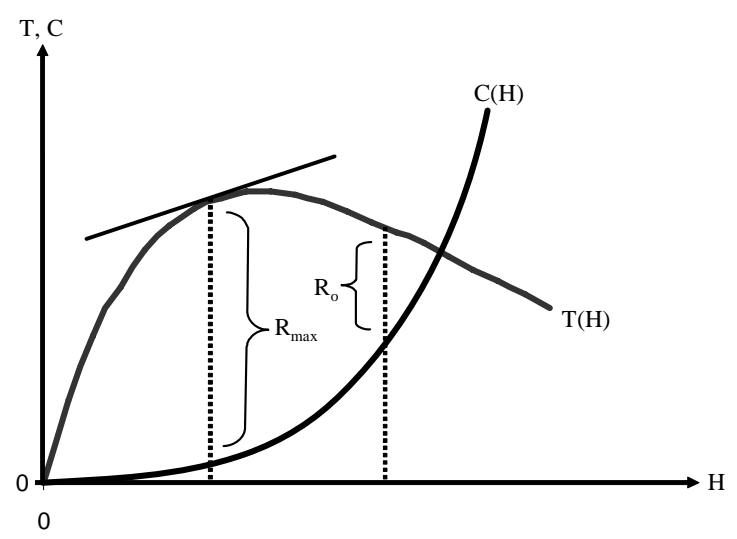

Formerne af produktionsfunktionen (2), samt af sammenhængen mellem ændringer i havdage og biomasse (3) er illustreret grafisk i hhv. figur 2 og 3.

Figur 2. Kalibrering af produktionsfunktionen.

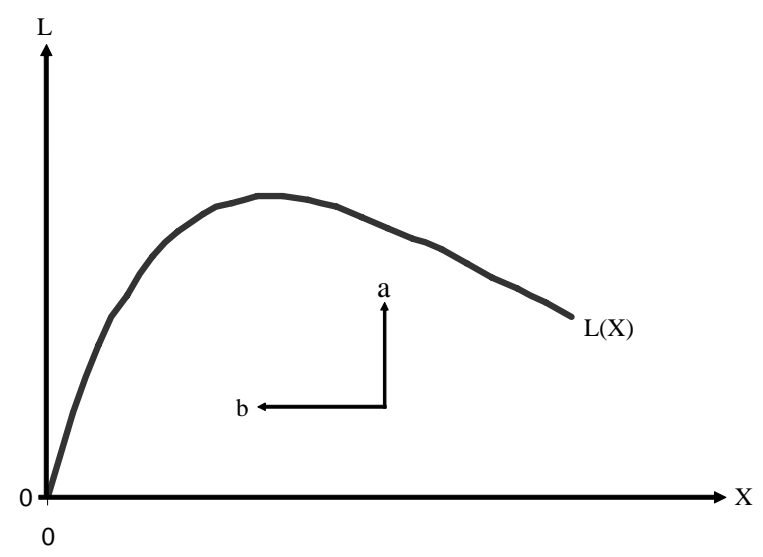


Figur 3. Sammenhæng mellem ændring i havdage og biomasse.

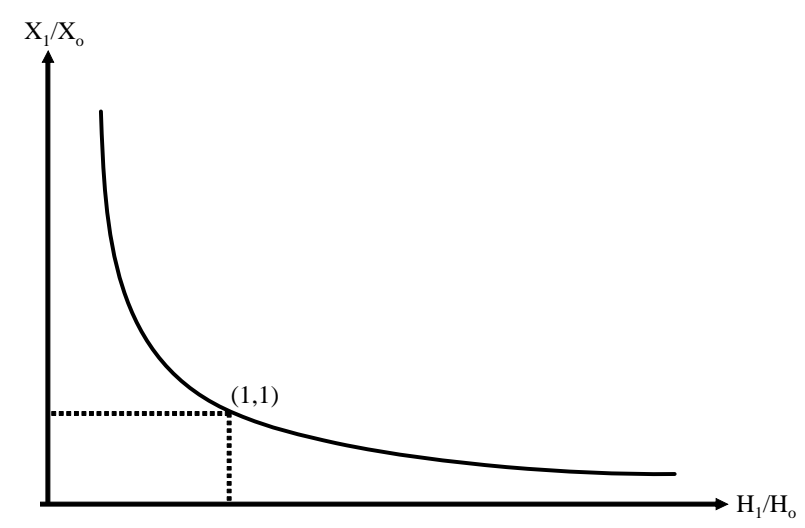

Produktionsfunktionen i den i (2) angivne formel kalibreres for bestande, der eksisterer biologiske vurderinger af, givet viden om den nuværende biomasse, den maksimale biologiske biomasse og den betragtede flådes faktiske fiskeri på de enkelte bestande. Fiskeri på de bestande, der ikke eksisterer biologiske oplysninger for, antages at udvikle sig præcist som dem, der eksisterer biologiske oplysninger for.

Ovenstående model er alene gennemgået for et enartsfiskeri. I flerartsfiskerier antages yderligere, at de enkelte flådesegmenters fiskeri på forskellige bestande er uafhængigt af hinanden, samt at de enkelte flådesegmenters relative tidsforbrug på de forskellige bestande er konstant. Dette indebærer bl.a. at fiskerimønsteret er upåvirket af ændringer i øvrigt.

Den maksimale ressourcerente findes i flerartsfiskerier ved at vurdere effekten på ressourcerenten i fiskeriet på alle bestande med samtidige og lige store ændringer i antallet af havdage. Dette er illustreret grafisk i figur 4, som sammenligner den nuværende situation med en tilfældig ny situation ved reduktion i fiskeriindsatsen.

Figur 4. Nuværende og maksimal ressourcerente i flerartsfiskerier.

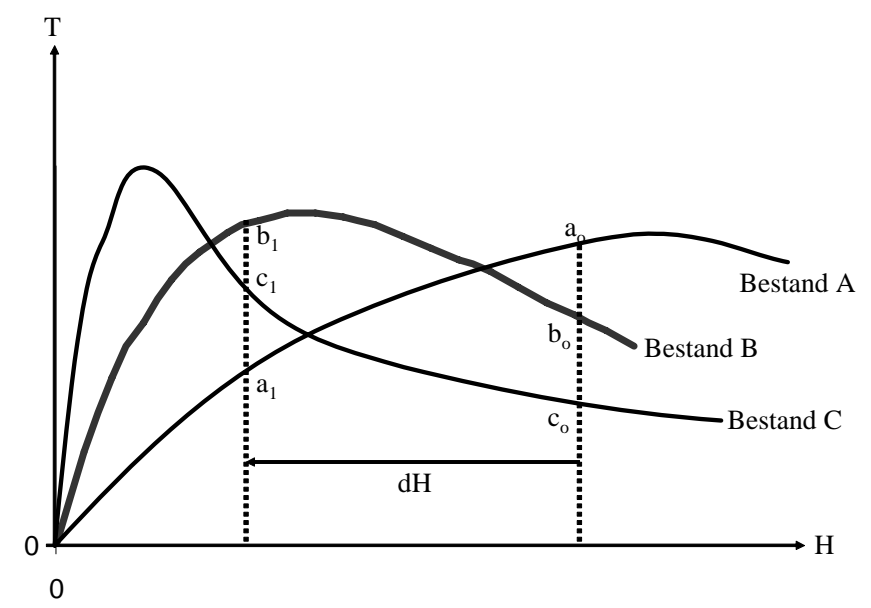


Gennem eksperimenter kan den maksimale ressourcerente (inkl. den infra-marginale rente) bestemmes. Denne holdes op mod antagelsen om initial ligevægt, hvilket er en rimelig antagelse, hvis fiskeriindsatsen i den nuværende situation er bæredygtig. Er fiskeriindsatsen ikke bæredygtig, er der forøget risiko for rekrutteringsproblemer og herigennem svigtende fremtidige fangster. Derved kan den maksimale ressourcerente være overvurderet. 